\title{
Malformations of Cortical Development and Epilepsy
}

\author{
A. James Barkovich ${ }^{1}$, William B. Dobyns ${ }^{2}$, and Renzo Guerrini ${ }^{3}$ \\ ${ }^{1}$ Department of Radiology and Biomedical Imaging, Neurology, Pediatrics, and Neurosurgery, \\ University of California, San Francisco, San Francisco, California 94143-0628 \\ ${ }^{2}$ Center for Integrative Brain Research, Seattle Children's Research Institute, Seattle, Washington \\ 98101 \\ ${ }^{3}$ Pediatric Neurology Unit and Laboratories, Children's Hospital A. Meyer, University of Florence, \\ Florence 50139, Italy \\ Correspondence: james.barkovich@ucsf.edu
}

\begin{abstract}
Malformations of cortical development (MCDs) are an important cause of epilepsy and an extremely interesting group of disorders from the perspective of brain development and its perturbations. Many new MCDs have been described in recent years as a result of improvements in imaging, genetic testing, and understanding of the effects of mutations on the ability of their protein products to correctly function within the molecular pathways by which the brain functions. In this review, most of the major MCDs are reviewed from a clinical, embryological, and genetic perspective. The most recent literature regarding clinical diagnosis, mechanisms of development, and future paths of research are discussed.
\end{abstract}

$M$ alformations of cortical development (MCDs) are common causes of medically refractory epilepsy, particularly in children (Barkovich et al. 2012). Although most childhood epilepsies respond to treatment, $\sim 15 \%$ are resistant to pharmacologic treatments (drug-resistant childhood epilepsies) (Guerrini 2006); $\sim 40 \%$ of these are caused by MCDs (Kuzniecky et al. 1993b; Frater et al. 2000; Pasquier et al. 2002). One type of MCD, called focal cortical dysplasia (FCD), has an incidence of $50 / 100,000 / \mathrm{yr}$ in children $<16 \mathrm{yr}$ of age, adding up to $\sim 0.8 \%$ of children (Nelligan and Sander 2011; Ngugi et al. 2011). Approximately $25 \%$ (range $10 \%-30 \%$ ) of patients with FCD progress to intractable epilepsy, enriched in those with focal epilepsies (Braathen and Theorell 1995; Wirrell et al. 2013). FCDs of all types are seen in $25 \%-100 \%$ of brain tissue from epilepsy surgery (Mischel et al. 1995; Tassi et al. 2002). Not all people with MCDs have epilepsy, however; presentations typically include variable levels of motor or cognitive impairment, but some are discovered incidentally after magnetic resonance (MR) scans for other medical conditions or unrelated events (e.g., injuries) (de Wit et al. 2008), whereas an unknown number are probably never detected.

Although MCDs have been known for many years and classified for $\sim 20$ years, the basic ge-

Editors: Gregory L. Holmes and Jeffrey L. Noebels

Additional Perspectives on Epilepsy: The Biology of a Spectrum Disorder available at www.perspectivesinmedicine.org

Copyright (C) 2015 Cold Spring Harbor Laboratory Press; all rights reserved; doi: 10.1101/cshperspect.a022392

Cite this article as Cold Spring Harb Perspect Med 2015;5:a022392 
A.J. Barkovich et al.

netic and molecular processes that underlie the development of these disorders has become much clearer in the past few years. The purpose of this review is to discuss the current classification and molecular underpinnings of these disorders. In doing so, we will concentrate on new concepts that have developed as a result of recent discoveries in the field.

\section{FRAMEWORK OF THE CLASSIFICATION}

In the initial classification in which the term "malformation of cortical development" was derived (Barkovich et al. 1996), the investigators separated the disorders into three main groups, based on the earliest stage development that is affected (recognizing that alteration of early developmental events often affects later events, as well): disorders caused by abnormal cell proliferation, abnormal neuronal migration, and abnormal postmigrational cortical development. The discovery of many genes, proteins, and pathways involved in these steps, however, has made the classification more complex in some areas and more simplified in others. In this review, we will first discuss the fundamental concepts underlying each major component of the classification, followed (when appropriate) by a discussion of new discoveries regarding gene mutations, the effects of these mutations on the function of their protein products, the consequent effects on molecular pathways, and how alterations of pathways affect brain development. In areas in which new discoveries have been few, and which, consequently, remain poorly understood, we will discuss potential reasons for the poor understanding.

\section{MALFORMATIONS SECONDARY TO ABNORMAL CELL PROLIFERATION OR APOPTOSIS}

A good deal of new information has become available over the past few years with regard to malformations in this category, in particular, pertaining to reduced cell proliferation (microcephalies) (Thornton and Woods 2009; Alkuraya et al. 2011; Bakircioglu et al. 2011; Bicknell et al. 2011) and malformations associated with abnormal cell proliferation (type II FCDs) (Blümcke et al. 2011), gangliogliomas (Boer et al. 2010; Koelsche et al. 2013), tuberous sclerosis complex (TSC) (Crino 2013), and megalencephalies associated with cerebral dysgeneses (Kurek et al. 2012; Lee et al. 2012; Riviere et al. 2012).

\section{Microcephalies}

Our understanding of microcephalies has increased greatly in the past few years with the discovery of the responsible genes and the functions of their protein products. Most of the responsible genes function in cell replication. For example, patients with microcephaly associated with osteodysplastic primordial dwarfism (MOPD), such as Meier-Gorlin syndrome, have mutations affecting subunits of the origin recognition complex, which is loaded onto chromatin at DNA origins before the $S$ phase of mitosis to license replication; in conjunction with additional components CDC6, CDT1, and MCM2-7, it forms the prereplication complex, which initiates DNA replication (Bicknell et al. 2011). Other genes that, when mutated, result in microcephaly include those involved in microtubule formation ( TUBA1A, TUBB2B, TUBB3, TUBG1) (Poirier et al. 2010, 2012, 2013; Cushion et al. 2013), those coding for microtubule-associated proteins (DYNC1H, KIF5C, NDE1) (McKenney et al. 2010; Alkuraya et al. 2011; Bakircioglu et al. 2011; Poirier et al. 2013), those involved in spindle organization and positioning (ASPM) (Desir et al. 2008; Passemard et al. 2009), those regulating centriole length (CENPJ) (Tang et al. 2009; Al-Dosari et al. 2010) or centrosome integrity (STIL) (Castiel et al. 2011), those that repair genomic defects and regulate genomic integrity (CEP152) (Kalay et al. 2011), and many others involved in the very complex process of cell replication. By a combination of clinical characteristics (Mahmood et al. 2011), imaging characteristics (Fig. 1) (Barkovich et al. 2012), and family histories, many of the causes of microcephalies can now be identified in families. 

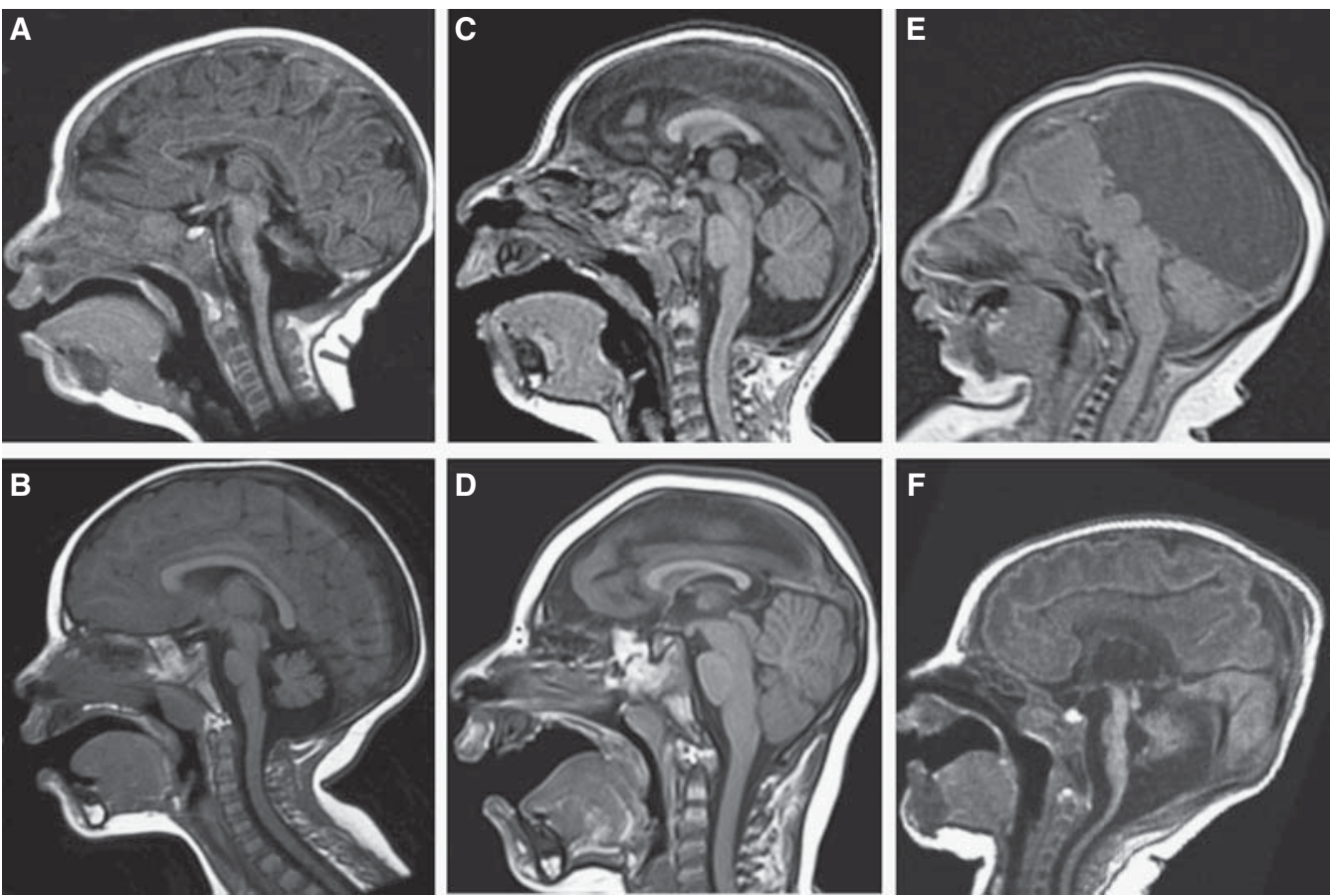

Figure 1. Sorting of microcephalies by morphologic characteristics. (A) Microcephaly with extremely small cerebellum and small pons. $(B)$ Microcephaly with cerebellum and pons that are proportional and slightly disproportionately small compared with cerebrum. (C) Profound microcephaly with proportional cerebellum and brainstem that are disproportionately large compared with cerebrum. (D) Severe microcephaly with brainstem that is disproportionately large compared with cerebrum and cerebellum that is disproportionately large compared with brain stem. (E) Microcephaly with absence of the corpus callosum, interhemispheric cyst, and proportional brain stem and cerebellum with cerebrum; posterior fossa structures appear small because of mass effect from the supratentorial cyst. $(F)$ Microcephaly with simplified cerebral gyral pattern, callosal hypoplasia, and severely disproportionately small brain stem and cerebellum.

\section{Malformations that May Be Associated with Mutations Affecting the Mammalian Target of Rapamycin (mTOR) Pathway}

For many years, several malformations caused by abnormal cell proliferation were thought to be related because of their similar histological appearances and MR imaging patterns (Barkovich et al. 2012). These included the brain lesions associated with TSC, a localized enlargement of dysmorphic and dysplastic brain called hemimegalencephaly (HME; also referred to as dysplastic megalencephaly), tumors with dysplastic features (ganglioglioma), and focal cortical dysplasia type IIb (FCD IIb) all are characterized by localized dysplastic, enlarged neurons, impaired myelination, and large, ovoid dysmorphic cells with laterally displaced nucleus and limited axons and dendrites called balloon cells (HMEs), giant cells (TSCs), or atypical ganglion cells (ATGCs) (gangliogliomas). In the past 2 years, it has become clear that all of these disorders, as well as others classified as malformations, as a result of abnormal cell proliferation, result from mutations affecting mTOR signaling pathways (Fig. 2). The mTOR signaling cascade functions as a central controller of organism growth and homeostasis; it integrates the input from upstream pathways, including insulin, growth factors (such as insulin-like growth factor [IGF]-1 and IGF-2), and amino acids and senses cellular nutrient, oxygen, and energy levels. Messenger RNA (mRNA) translation is suppressed in un- 
A.J. Barkovich et al.

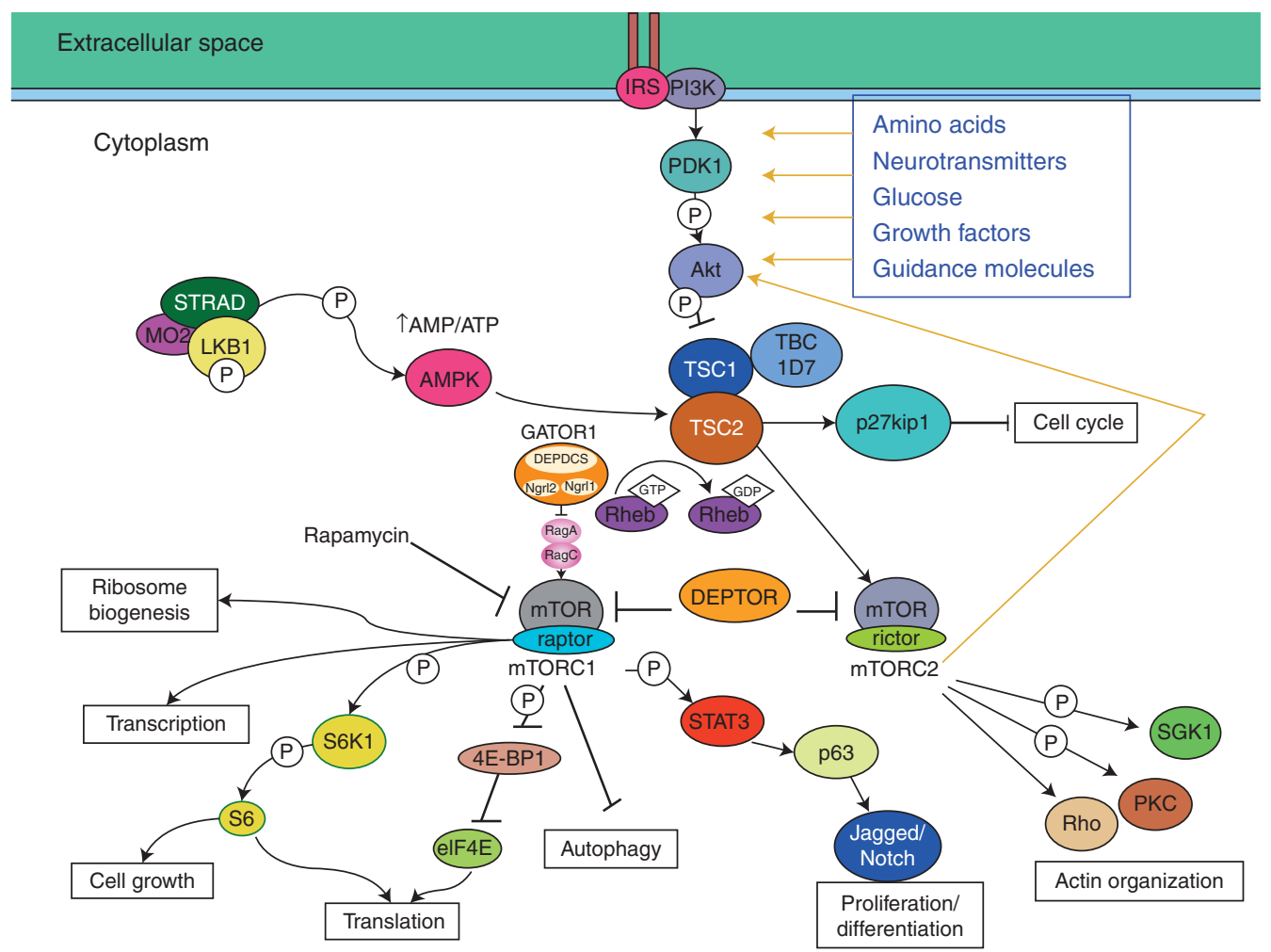

Figure 2. Diagram of portions of the mammalian target of rapamycin (mTOR) pathways associated with many aspects of cerebral cortical development, including transcription, cell growth, translation, proliferation/differentiation, and actin organization. As far as currently known, mTOR complex 1 (mTORC1) is more highly associated with cortical development than mTOR complex 2 (mTORC2). (Adapted from Lim and Crino 2013.)

favorable conditions, whereas translation, transcription, and (consequently) growth are stimulated under favorable conditions (Zoncu et al. 2011; Thoreen et al. 2012). mTOR is the catalytic subunit of two distinct complexes called mTOR complex 1 (mTORC1) and complex 2 (mTORC2), which are distinguished by accessory proteins of $\mathrm{mTOR}$. The molecular details of these signaling pathways can be found in many recent publications (Zoncu et al. 2011; Thoreen et al. 2012; Laplante and Sabatini 2013). An important concept is that the mTOR pathway can be activated or inhibited by a number of upstream signaling mechanisms, such as the insulin/phosphoinositide-3-kinase (PI3K)/AKT pathway or the adensosine monophosphate-activated protein kinase (AMPK) pathway, in response to environmental cues or metabolic demands (Zoncu et al. 2011; Thoreen et al. 2012;
Laplante and Sabatini 2013). The involvement of the mTOR pathway in regulating growth and proliferation of cells in the central nervous system (CNS) makes it a strong candidate to account for the abnormal cellular phenotypes (and, in some cases, increased proliferation) found in type II FCD (Blümcke et al. 2011), dysplastic (hemi)megalencephaly (Flores-Sarnat et al. 2003), ganglioglioma (Boer et al. 2010; Koelsche et al. 2013), and TSC (Tsai et al. 2012; Prabowo et al. 2013). Clinical presentation varies with the type of malformation, ranging from infantile spasms with a burst suppression pattern and/or hemihypsarrythmia on sleep electroencephalography (EEG) in the most severe cases to developmental delay with mental retardation and intractable partial motor or asymmetric tonic or clonic generalized seizures to isolated focal seizure disorders. Brain dysgenesis 
may be isolated or seen in conjunction with a neurocutaneous syndrome, such as TSC, hypomelanosis of Ito, or epidermal nevus syndrome (Bulteau et al. 2013).

Recent publications have implicated mutations of a number of genes involved in the mTOR pathways in the pathogenesis of malformations secondary to abnormal cell proliferation. These include $P I 3 K$ and $A K T 3$ in dysplastic megalencephaly (DMEG) (Lee et al. 2012; Poduri et al.2012), mutations of AKT3 and PIK3R2 in megalencephaly-polymicrogyria-polydactyly-hydrocephalus (MPPH) syndrome (Riviere et al. 2012), mutations of PIK3CA in megalencephaly-capillary malformation (MCAP) syndrome (Lee et al. 2012), and congenital lipomatous overgrowth, vascular malformations, and epidermal nevi (CLOVE) syndrome (Kurek et al. 2012). The work on AKT3 (Poduri et al. 2012) is particularly compelling for control of proliferation (and, consequently, brain size) as the mouse Akt3 knockout (KO) model shows selective reduction in brain size because of decreased neuronal number and size (Easton et al. 2005), whereas mice with activating mutations of the kinase domain of $A k t 3$ show enlarged hippocampi (Tokuda et al. 2011) and humans with duplications or activating point mutations had hemispheric brain overgrowth (Poduri et al. 2012). More important is the observation that these mutations are somatic (not present in other family members) and mosaic (they are present in only a subset of cells of the affected individual). Therefore, genetic testing of other family members will not be helpful and testing of skin or blood cells of affected individuals may not show the mutation responsible for the brain malformation. Indeed, the observation that only a subset of cells contains the mutation in DMEG, in which the entire hemisphere is typically malformed, suggests that both cell-autonomous and non-cell-autonomous mechanisms are at work (Lim and Crino 2013; Poduri et al. 2013). In contrast, germline mutations of TSC1 or TSC2 are present in patients with TSC, and recent investigations have shown activation of the mTORC1 and mTORC2 pathways in brain lesions of fetuses with TSC (Tsai et al. 2012; Prabowo et al. 2013), yet only a few tubers are typically present in the brain. This has prompted some investigators to propose a "two-hit" hypothesis, suggesting presence of both germline and somatic mutations with biallelic gene inactivation (Crino et al. 2010; Poduri et al. 2013); other studies suggest that second hits are rare (Qin et al. 2010).

Some investigators have proposed that somatic mutations of mTORC1 pathway genes may be associated with the pathogenesis of FCD II (Lim and Crino 2013). The authors have each experienced a number of patients with, apparently, localized FCD IIb that continued to have refractory seizures after lesionectomy or hemispherotomy to isolate the visible dysplastic tissue. Subsequently, hemispherectomy, in all cases, revealed much more extensive dysplasia than was visible by magnetic resonance imaging (MRI), including balloon cells and large, dysmorphic neurons, as was described previously by D'Agostino et al. (2004). Indeed, imaging studies of DMEG have emphasized the heterogeneity of the findings on MRI (Barkovich and Chuang 1990; Nakahashi et al. 2009) and have shown that the cerebellum may be affected as well (Sener 1997; Di Rocco et al. 2001). These findings suggest that DMEG may be more heterogeneous within the affected hemisphere than has been generally recognized and that FCD II, particularly FCD IIb as it has nearly identical histology, may represent a region of increased severity in a hemispheric disorder. Future studies of FCD II to look for alterations of mTORC1 may be useful in this regard.

Gangliogliomas are interesting lesions from both a developmental and clinical perspective. They are the most common neoplasm associated with pediatric epilepsy and represent 5\% of pediatric brain tumors. The tumors are defined histologically by a loss of cortical lamination, proliferation of glial cells, and the presence of dysmorphic neurons and ATGCs. The dysmorphic neurons and ATGCs resemble the cellular morphologies of the dysmorphic neurons and the giant cells/balloon cells seen in TSC, DMEG, and FCD IIb, and the latter cells express similar protein markers, such as Sox2, Oct4, and Klf4 (Orlova et al. 2010). About 30\% of gangliogliomas are associated with FCD, which 
A.J. Barkovich et al.

are either connected to the tumor or directly adjacent to it (Blümcke et al. 2011). Several studies have suggested activation of mTOR pathway in gangliogliomas with p70S6 kinase, S6 phosphorylation, and a protein profile very similar to that of FCD IIb (Boer et al. 2010). In addition, an identical and common somatic V600E mutation in $B-R A F$, a known pathogenic gene for melanoma and papillary thyroid cancer that has been linked to enhanced mTOR signaling via LKB1 and mTORC2/Akt, has been detected in up to $58 \%$ of resected specimens, mainly in the neuronal and ATGC components (Chen et al. 2012; Faustino et al. 2012; Koelsche et al. 2013).

\section{MALFORMATIONS SECONDARY TO ABNORMAL CELL MIGRATION}

Malformations secondary to abnormal cell migration include heterotopia, lissencephaly, and so-called cobblestone malformations, which result from lack of attachment of radial glial cells (RGCs) to the pial-limiting membrane (PLM) and consequent gaps in that membrane.

\section{Malformations Secondary to Tubulin and Microtubule-Associated Protein Anomalies}

Microtubules are of critical importance in brain development. They are essential in steps of "cell proliferation" (mitosis) and "neuronal migration" (critical in the extension of the leading processes of migrating neurons and interkinetic nuclear migration (McKenney et al. 2010; Kuijpers and Hoogenraad 2011; Huang et al. 2012) in the cerebrum, cerebellum, and brain stem. Microtubules also play critical roles in "axonal path finding" (a process similar to the extension of leading processes of migrating neurons) (Dent et al. 2011). As a result, abnormalities of microtubule formation (tubulinopathies) are typically characterized in the brain by microcephaly, abnormalities of neuronal migration (resulting in gray matter heterotopia or cortical dysgenesis/lissencephaly in the cerebrum and hypoplasia/dysgenesis of the cerebellum), anomalies of axonal pathfinding (diminished white matter volume, corpus callosum dysgenesis, cranial nerve hypoplasia or aplasia, olfactory nerve/sulcus dysgenesis, and malformations of the brain stem), or a combination thereof (Bahi-Buisson et al. 2008, 2013; Kumar et al. 2010; Tischfield et al. 2010; Guerrini et al. 2012; Chew et al. 2013; Cushion et al. 2013; Poirier et al. 2013; Saillour et al. 2013).

Recent classifications of malformations secondary to abnormal neuronal migration have listed classic lissencephalies (agyria-pachygyria) and variant lissencephaly (caused by $A R X$ and Reelin pathway mutations) as the two principal categories. Recent work, however, has shown that all of the six grades of classic lissencephalies (Table 1) are caused by mutations of genes encoding tubulins (primarily TUBA1A) (Poirier et al. 2007) or proteins that function in conjunction with microtubules (microtubule-associated proteins or MAPs, such as DCX, LIS1, cytoplasmic dynein, kinesins, NudE) (Dobyns et al. 1993; Gleeson et al. 1998; Toyo-oka et al. 2003; Lecourtois et al. 2010; Cushion et al. 2013; Poirier et al. 2013). As mutations of genes encoding tubulins and MAPs are associated with, and likely responsible for, other MCDs (such as heterotopia and polymicrogyria [PMG]-like cortex) (Poirier et al. 2010, 2012; Guerrini et al. 2012; Cushion et al. 2013), one might consider altering the classification to make malformations

Table 1. Grading system for classic lissencephalies

\begin{tabular}{ll}
\hline Gradient & \multicolumn{1}{c}{ Grade of severity } \\
\hline $1 \mathrm{a}=\mathrm{p}$ & $\begin{array}{l}\text { Complete agyria } \\
\text { Diffuse agyria with a few } \\
\text { undulations at the } \\
\text { frontal or occipital poles } \\
\text { Mixed agyria and } \\
\text { pachygyria }\end{array}$ \\
$3 \mathrm{p}>\mathrm{a}$ or $3 \mathrm{a}>\mathrm{p}$ & $\begin{array}{c}\text { Diffuse pachygyria, or } \\
\text { mixed pachygyria and } \\
\text { normal or simplified } \\
\mathrm{p}>\mathrm{a} \text { or } 4 \mathrm{a}>\mathrm{p}\end{array}$ \\
$\begin{array}{l}\text { gyri } \\
\mathrm{a}>\mathrm{p} \text { (the reverse 5p }\end{array}$ & $\begin{array}{c}\text { Mixed pachygyria and } \\
\text { subcortical band } \\
\text { heterotopia }\end{array}$ \\
$6 \mathrm{p}>$ has not been $6 \mathrm{a}>\mathrm{p}$ & $\begin{array}{c}\text { Subcortical band } \\
\text { heterotopia only }\end{array}$ \\
\hline
\end{tabular}

a, Anterior location of malformation; p, posterior location. 
secondary to mutations of tubulin and MAP genes as a major category of MCD with classic lissencephalies as a subcategory. It will be interesting to determine what differences are seen in the mutations of genes coding for MAPs as compared with those coding for the tubulins themselves.

\section{Phenotypes}

As mentioned above, the category of classic lissencephaly can be divided into six grades based on the severity of the malformation (Table 1), and examples of all grades of lissencephaly can be found as a result of mutations of genes for tubulins or MAPs (Bahi-Buisson et al. 2008, 2013; Kumar et al. 2010; Guerrini et al. 2012; Cushion et al. 2013; Poirier et al. 2013). The reason for this is that the phenotype resulting from a tubulin mutation depends on the effects of the mutation on the three-dimensional structure of the resultant microtubule (Cushion et al. 2013; Poirier et al. 2013) and its ability to properly interact with specific MAPs or other heterodimers of tubulin A and B (microtubules are long hollow cylinders with walls composed of heterodimers of tubulin A and tubulin B, which polymerize end-to-end to form "protofilaments," the building blocks for microtubules). Protofilament polymerization and depolymerization are critical steps, along with actin polymerization and depolymerization, in the pathfinding of axonal growth cones and the leading processes of migrating neurons (Marin et al. 2010; Tischfield et al. 2010; Dent et al. 2011). If a mutation alters the speed of polymerization or depolymerization of protofilaments, the growth cones of axons cannot rapidly respond to attractive and repulsive cues in their immediate environment causing misdirection and retraction of growth cones with ultimate hypoplasia of white matter pathways/cranial nerves (leading to olfactory nerve hypoplasia, congenital fibrosis of the extraocular muscles, corpus callosum hypoplasia, lack of separation of caudate and putamen caused by absence of the anterior limb of the internal capsule) (Tischfield et al. 2010; Chew et al. 2013) or ectopic white matter pathways, such as dysgenesis of corpus callosum or brain stem (Figs. 3 and 4) (Poirier et al. 2013). In contrast, when the mutations affect the binding sites of MAPs or other proteins that affect the interaction of MAPs with the microtubules ( for example, altering binding of LIS1 to its binding site impairs the function of cytoplasmic dynein in interkinetic nuclear migration [Huang et al. 2012; Splinter et al. 2012], which is critical for neuronal migration), the results are pachygyria or frank lissencephaly (Poirier et al. 2013) or, possibly, PMG-like cortex and gray matter heterotopia (Cushion et al. 2013). It is also possible that the impaired migration of neurons to the cortex results in migration of fewer axons, resulting in diminished white matter volume.

\section{Variant Lissencephalies}

Lissencephaly can be very different, genetically, clinically, and on imaging, from the classic lissencephaly/pachygyria/band heterotopia spectrum associated with tubulin and MAP abnormalities. In both $A R X$ mutations and mutations of the Reelin signaling pathway, affected patients vary widely in clinical severity depending on the gene affected and the severity of the mutation, although most patients have severe, early-onset epilepsy (Hong et al. 2000; Kitamura et al. 2002; Stromme et al. 2002; Kato et al. 2004; Boycott et al. 2005; Glass et al. 2005). Imaging characteristics of these "variant" lissencephalies have fairly distinctive imaging characteristics (of varying severity), which allow identification in most cases; the cerebral cortex is slightly thick (5-7 $\mathrm{mm})$ with an anterior (less severe) to posterior (more severe) gradient, variable hyposulcation, and no cell-sparse zone. $A R X$ mutations have absence of the corpus callosum and, typically, small dysplastic basal ganglia (Bonneau et al. 2002), whereas Reelin pathway disorders show cerebellar hypoplasia of varying severity (Hong et al. 2000; Bonneau et al. 2002; Boycott et al. 2005; Glass et al. 2005; Miyata et al. 2009) and granule cell dispersion in the hippocampus (Haas and Frotscher 2010).

Reelin has multiple functions in cerebral development. It acts upstream of Notch signaling, which, in its most classical function, inhibits 
A.J. Barkovich et al.
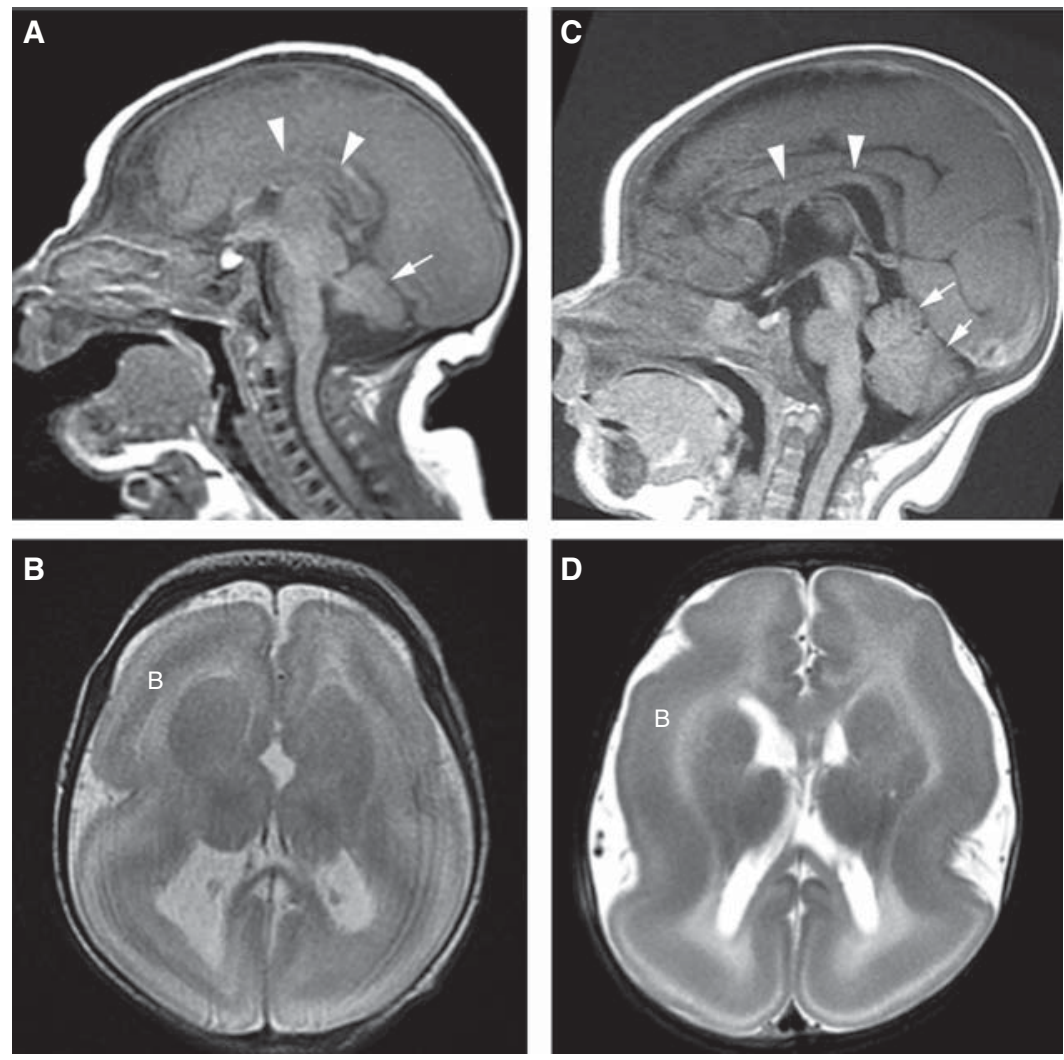

Figure 3. Lissencephaly secondary to $\operatorname{TUBA} 1 A(A, B)$ and $\operatorname{LIS1}(C, D)$ mutations. Note that the child with the TUBA1A mutation is smaller, the corpus callosum (arrowheads) is thinner (difficult to see), and the cerebellum is small. Both are characterized by a band (B) of incompletely migrated neurons deep to the cortex.

neural differentiation and maintains neuroepithelial fate, thus, preventing depletion of neuronal precursor cells (Bolós et al. 2007). It also regulates the temporal specification of intermediate precursor cells (IPCs), transformation of radial glia to astrocytes, and controls the translocation of Golgi vesicles into the leading process of migrating neurons, thereby coupling neocortical neurogenesis to neuronal migration and, probably, astrogliogenesis (Lakomá et al. 2011; Meseke et al. 2013a,b). In addition, Reelin acts during the late phases of neuron migration to allow the leading process of a migrating neuron to bypass cortical neurons that have migrated previously. In the mouse, Sekine et al. (2012) have recently defined a large portion of this intracellular pathway, which starts with Reelin binding to Apoer2 and Vldlr, and ends with change in the conformation of integrin $\alpha 5 \beta 1$ (for details, see Sekine et al. 2012). After this activation, integrin adheres to fibronectin on Cajal-Retzius cells in the molecular zone, allowing the neuron to pass preceding neurons in the primitive cortical zone and enter the outermost submolecular layer currently forming in the cortex (Fig. 5A) (Sekine et al. 2012). In the cerebellum, Purkinje cells form clusters deep within the cerebellar hemispheres until Reelin, secreted by the migrating granule neurons in the external granular layer (D'Arcangelo et al. 1995, 1997), binds to Apoer2 or Vldlr receptors on the Purkinje cells and activates a protein kinase cascade that (ultimately) decreases inter-Purkinje adhesion and allows dispersion of the embryonic clusters. Thus, liberated, the Purkinje cells form their characteristic stripes and begin 

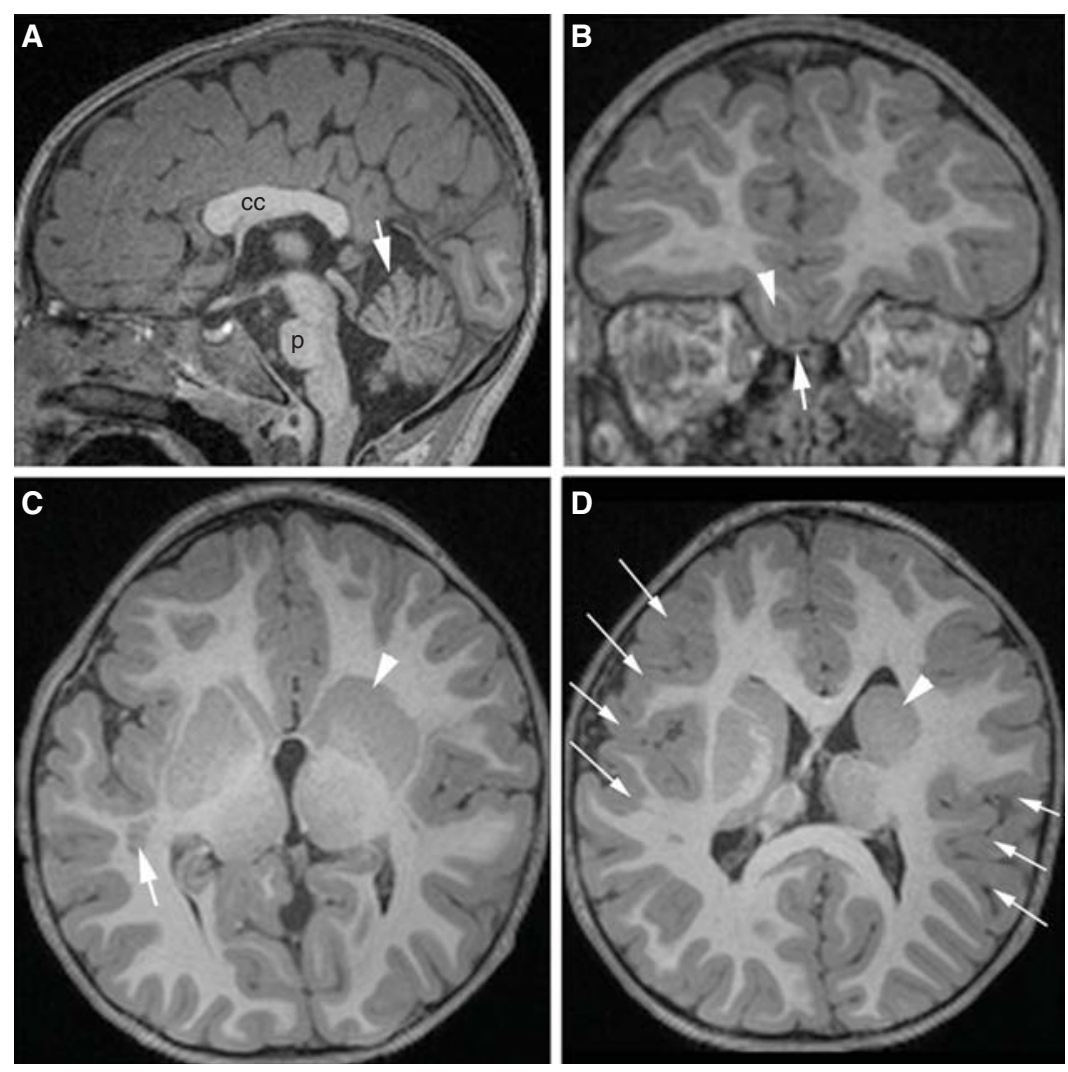

Figure 4. Magnetic resonance imaging (MRI) of patient with TUBB2B mutation showing many aspects of "tubulinopathies." Sagittal image $(A)$ shows short corpus callosum (cc), small pons (p), and small anterior lobe of cerebellum (white arrow). Coronal image $(B)$ shows normal olfactory sulcus (arrowhead) and bulb (arrow) on the right, but absent sulcus and bulb on the left, an axonal pathfinding disorder. $(C)$ Axial images show gray matter heterotopia (neuronal migration disorder, arrow), absent anterior limb of the internal capsule (axonal pathfinding disorder, arrowheads in $C$ and $D$ ), and $(D)$ abnormal sulcation in bilateral perisylvian cortex (arrows).

to establish connections within and outside of the cerebellum (Dastjerdi et al. 2012). Infants with mutations of the Reelin pathway are severely developmentally impaired with marked hypotonia at birth, marked global delays in development, and onset of generalized epilepsy at an early age (Hourihane et al. 1993). The MRI phenotype of Reelin pathway disorders is characteristic (Fig. 5B-D), with some variations, but it is not yet clear whether the variations are more a result of the gene that is mutated or the effect of the mutation on the function of the protein product in the pathway. In addition to the thick cerebral cortex with anterior to posterior gradient, cortical sulcation is simplified, varying from mild simplification secondary to absence of tertiary cerebral sulci in VLDLR mutations to very simplified with only a few, relatively deep sulci present. The cerebellum is small, particularly the vermis, and also has very simplified foliation (completely smooth in severe cases). Hippocampi are incompletely rotated (Hong et al. 2000; Bonneau et al. 2002); this may be related to the severe epilepsy, likely related to developmental dispersion of granule cells in the hippocampi of affected individuals (Haas and Frotscher 2010). We have performed genetic testing on some patients with features suggestive of Reelin pathway abnormalities, but results have been negative. Whether these patients have 
A.J. Barkovich et al.

A
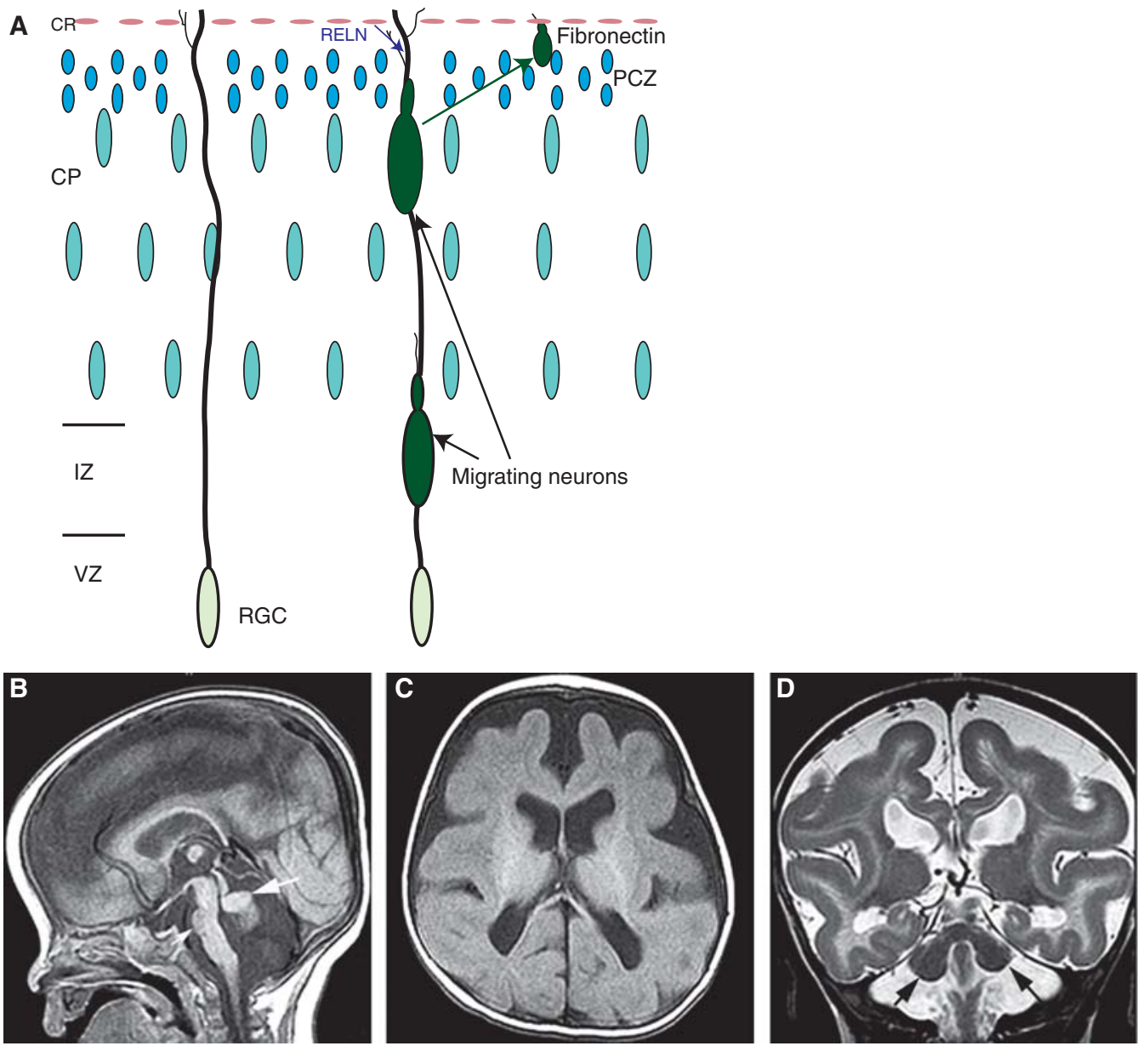

Figure 5. Schematic of Reelin effects on terminal neuronal migration and images of brain with RELN mutation. (A) Schematic of neurons migrating along radial glial cell (RGC). The migrating neuron is unable to pass the primitive cortical zone (PCZ) before Reelin (RELN) from the Cajal-Retzius (CR) cells activates the Reelin pathway, resulting in a change in the conformation of integrin $\alpha 5 \beta 1$. This integrin is then able to adhere to fibronectin on CR cells in the molecular zone, allowing the neuron to pass through the PCZ and enter the outermost submolecular layer currently forming in the cortex. $(B-D)$ show magnetic resonance imaging (MRI) of an infant with a RELN mutation. Note the small, smooth cerebellar vermis (large white arrow in $B$ ) and hemispheres (black arrows in $D$ ), the small pons (small white arrow in $B$ ), and the very simplified cerebral gyral pattern (in $C$ and $D$ ) with a thick cerebral cortex (seen best in $D$ ).

mutations of Reelin pathway genes that have not yet been identified or whether a similar phenotype may be a result of mutations in other pathways has not been determined.

$A R X$ is an extremely important gene in cortical development as ARX regulates genes involved in cell migration, axonal guidance, neurogenesis, and transcription regulation ( $\mathrm{Co}-$ lombo et al. 2007; Colasante et al. 2008, 2013;
Fulp et al. 2008; Okazaki et al. 2008), although the mechanisms are not yet known. Because ARX interacts with many different targets during development, mutations cause a wide range of abnormalities, including mental retardation (syndromic and nonsyndromic), infantile spasms without brain malformations, dyskinesia, agenesis of the corpus callosum with abnormal genitalia, variant lissencephaly with dys- 
morphic basal ganglia, and hydranencephaly (Kato et al. 2004; Okazaki et al. 2008). ARX mutants with large deletions, frameshifts, nonsense mutations, and splice site deletions develop a very severe syndrome known as XLAG (X-linked lissencephaly with agenesis of the corpus callosum and abnormal genitalia), which is also associated with abnormalities of the basal ganglia and cerebellum and, in the most serious cases, with hydranencephaly, a disorder in which large portions of the cerebral hemispheres appear to have been destroyed (Kato et al. 2004). Affected patients develop generalized, difficult-to-control seizures in the first hours of life (or before birth), often manifesting tonic spasms of the extremities, severe hypotonia, craniofacial dysmorphisms, poor neonatal reflexes, a small penis, and undescended testes (Bonneau et al. 2002).

The cortical malformation in ARX-associated lissencephaly has been described as a threelayer cortex in which the number of neurons in the brain is markedly diminished. The outer cortical layer is a rather thick molecular layer that consists mainly of scattered small- to medium-sized neurons (Bonneau et al. 2002; Forman et al. 2005; Okazaki et al. 2008). Immediately below is a hypercellular layer composed of mainly small neurons with a relative increase (compared with layer 1) in pyramidal cells. The third layer is thick, containing sparsely distributed small- and medium-sized neurons, including pyramidal neurons of various sizes; no myelinated axons are detected (Forman et al. 2005; Okazaki et al. 2008). A few scattered neurons and very few myelinated axons are seen in the white matter. Recently, Colasante et al. (2013) reported data suggesting that Arx regulates the expansion of both RGCs and, with a more pronounced effect, intermediate progenitor cells and that mutations of Arx result in reduced production of both GABAergic and glutamatergic cortical neurons. In addition, they identified a cohort of genes whose expression is consistently altered in the cerebral cortices of $\operatorname{Arx~KO}$ mice compared with wild-type mice (Colasante et al. 2013). Among these genes was $C d k n 1 c$, which encodes a member of the Cip/Kip family of cyclin-dependent kinase inhibitors.
CDKN1C antagonized cell-cycle progression by inhibiting $G_{1} / S$ transition (Sherr and Roberts 1999). They proposed that ARX may regulate cortical progenitor pool expansion by repressing expression of $C d k n 1 c$ in the developing cerebrum. Despite these recent advances, much remains to be understood about the many functions that ARX and its loss have on brain development.

\section{Gray Matter Heterotopia}

Heterotopia are accumulations of normal-appearing neurons in abnormal locations. They may be isolated or associated with other cerebral or extracerebral disorders. Approximately 90\% of patients with the simpler forms of heterotopia (periventricular nodular [PNH; Fig. 6A] and subcortical heterotopia) have epilepsy, which can begin at any age, from infancy to adulthood, although isolated heterotopia may be found incidentally in patients of any age who have MR imaging for unrelated causes. Partial epilepsy with temporo-occipital auras is the most common type (Dubeau et al. 1995, 1999). Localization of the epileptogenic area is complex, as the heterotopia may be functionally active and engage in complex epileptogenic networks that involve the overlying cortex, which is usually reorganized (Preul et al. 1997; Richardson et al. 1998; Mai et al. 2003; Tassi et al. 2005). Although ictal single-photon emission-computed tomography (SPECT) suggests that seizures arise from the heterotopic area (Odabasi et al. 1997), studies with depth electrodes in a few patients with deeply located nodules have shown that seizure activity may originate within both the heterotopic nodule and the overlying cerebral cortex (Tassi et al. 2005), or just within the nodule (Scherer et al. 2005). Patients with band heterotopia (also called laminar heterotopia or double cortex) typically present with epileptic seizures (47\%), including infantile spasms or developmental delay (16\%) (Barkovich et al. 1994; Bahi-Buisson et al. 2013). Most have intellectual disability with impairments that include abnormal language development and significant behavioral disturbances, such as hyperkinetic movements, crying, and, occa- 
A.J. Barkovich et al.

A

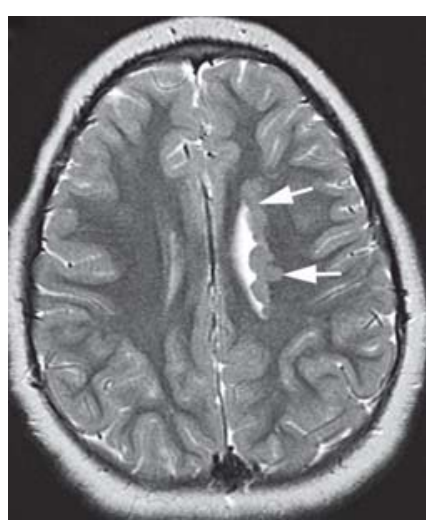

B

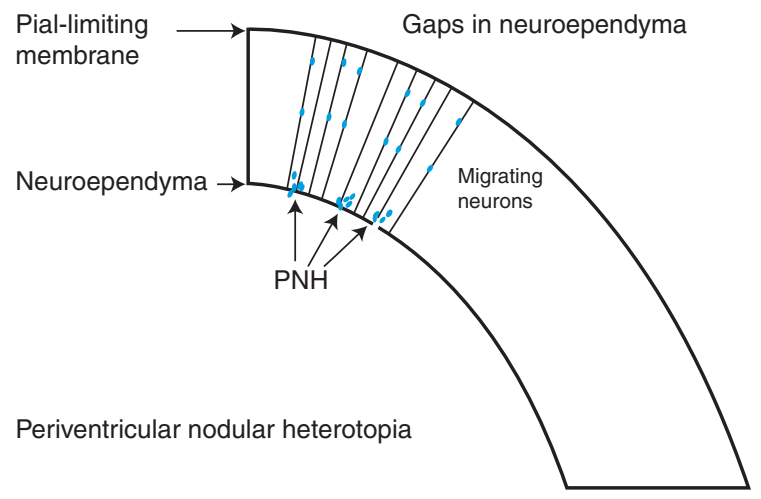

Figure 6. Periventricular nodular heterotopia (PNH). (A) An axial magnetic resonance imaging (MRI) scan shows nodules of gray matter intensity (arrows) along the left lateral ventricles, a characteristic appearance of PNH. (B) A schematic illustrating the mechanism of PNH formation. Disruption of neuroependyma, possibly because of disrupted vesicular trafficking, results in "gaps" in the membrane and disrupted neuroependymal attachment of the radial glial cells (RGCs). Neurons produced in the ventricular zone are not connected to the RGCs and are unable to migrate, remaining at or near the ventricular border as nodules of neurons.

sionally, autistic features (Bahi-Buisson et al. 2013). Rarely, they may develop normally until epilepsy begins in adulthood.

Simple forms of heterotopia, such as $\mathrm{PNH}$, are localized. Typically, a few nodules lie immediately adjacent to the ventricular wall or a few millimeters away from it; the neurons may be arranged in a pattern suggestive of laminar organization (Garbelli et al. 2009), and they contain primarily later-born neurons (Ferland and Guerrini 2009). PNH is often associated with other malformations, which vary with the location of the heterotopia; patients with posterior (trigonal, occipital, and temporal horns) $\mathrm{PNH}$ have a high incidence of cerebellar dysgenesis, corpus callosum anomalies, under-rotated hippocampi, and temporal lobe cortical dysgenesis of various types (Pisano et al. 2012; González et al. 2013; Mandelstam et al. 2013). More complex forms include subcortical heterotopia, which are a continuous, often swirling conglomeration of neurons that extend from the ependyma to the cortex; a subset of these contain colony-stimulating factor (CSF) and blood vessels and are continuous with the subarachnoid space (Barkovich 2000). Band heterotopia is best considered a mild form of lissencephaly; affected patients have a wide range of clinical manifestations that are related to the thickness of the band and the altered sulcation of the overlying cortex (Barkovich et al. 1994).

Neurogenetic analyses have identified two human genes (FLNA and ARFGEF2) that are known to cause PNH; other genetic abnormalities associated with $\mathrm{PNH}$ include duplication of 5p15 (anterior PNH) (Sheen et al. 2003), deletion 6p25 (with white matter anomalies) (Cellini et al. 2012), 7q11.23 (with Williams syndrome) (Ferland et al. 2006; Ramocki et al. 2010), 1p36 monosomy (with corpus callosum agenesis) (Neal et al. 2006; Shiba et al. 2013), 5q14.3-q15 (Cardoso et al. 2009), and 6q terminal deletion (Conti et al. 2013). The most common is inherited in an X-linked-dominant manner from mutations of FLNA (Fox et al. 1998). FLNA is an actin-binding protein that serves as a scaffold for many proteins; therefore, $\mathrm{PNH}$ has been assumed to result solely from impaired neuronal migration from the ventricular and subventricular zones (Fox et al. 1998; Barkovich et al. 2001). However, the discovery that PNH is also found (associated with microcephaly) in patients with mutations of the ARFGEF2 microcephaly gene (Sheen et al. 2004) has altered this 
concept. ARFGEF2 encodes BIG2 (Brefeldin-A inhibited guanine exchange factor-2), a protein kinase A-anchoring protein that regulates Golgi-vesicle trafficking (Sheen et al. 2004). Ferland and Guerrini (2009) presented strong evidence that $\mathrm{PNH}$ is not solely the result of impaired migration, but can arise from defects of the neuroependyma. They suggested that such defects result in impaired adhesion of neural progenitors and radial glial endfeet to the neuroepithelium (neuroependyma), resulting in an inability to engage and migrate along radial glia. Other animal work has shown that mutations of ARFGEF2 result in an increase in FLNA (Zhang et al. 2013). Sheen (2012) has proposed that the underlying problem is alterations of vesicular trafficking, which results in disruption of the neuroependymal continuity after replication and migration of neuroepithelial cells near the ventricular lining. Ependymal disruptions may explain many observed sporadic heterotopia (Fig. 6B).

\section{Cobblestone Malformations}

Formerly known as type II lissencephaly (Dambska et al. 1983; Dobyns et al. 1985) because the outer surface of the brain was rather smooth (with small surface bumps from the presence of neurons in the subarachnoid spaces), the true nature of cobblestone malformations began to be evident after the discovery that many of the affected patients had congenital muscular dystrophies, associated with elevated serum creatine kinase levels, hypotonia, and, often, cardiac involvement after the first decade. Affected patients also have ocular anomalies, including myopia, cataracts, retinal detachment, microphthalmia, buphthalmos, persistent hyperplastic primary vitreous, or congenital glaucoma. Medically refractory epilepsy is seen in some forms (Di Rosa et al. 2011; Barone et al. 2012), but is uncommon.

When MRIs of affected patients began to be performed, they showed cerebral cortical dysgenesis, abnormalities of myelination, and marked disturbances of brain stem and cerebellar development (Van der Knaap et al. 1997; Barkovich 1998). The brain, muscle, and ocular anomalies all result from abnormal linkage of basement membrane to muscle cells or (in the brain and eye) radial glia transporting migrating cells (de Bernabe et al. 2003; Beltran-Valero de Bernabe 2004; van Reeuwijk et al. 2005, 2006, 2007, 2010). As the linkages seemed to depend on glycosylation of $\alpha$-dystroglycan $(\alpha-D G)$ on the muscle fibers/radial glial endfeet, these disorders became known as dystroglycanopathies (Martin 2005), although the term "cobblestone malformation" is currently preferred. In the brain, abnormal glycosylation of $\alpha-D G$ on the radial glial endfeet was found to be associated with defects of the PLM (also called the glia limitans) (Myshrall et al. 2012), and with abnormal connection of the radial glia to the membrane. Mutations of laminins, the receptors for $\alpha$-DG in the PLM, are another cause of cobblestone malformations (Vigliano et al. 2009; Barak et al. 2011; Radmanesh et al. 2013; Radner et al. 2013), as are mutations of GPR56 (also located on radial glia endfeet) and its collagen receptors in the PLM (Li et al. 2008; Bahi-Buisson et al. 2010; Labelle-Dumais et al. 2011; Luo et al. 2011, 2012).

Clinical phenotypes vary widely and correlate less with the mutated gene than with the effect of the specific mutation on the RGCPLM linkage and the integrity of the PLM. The severity and clinical phenotypes of these disorders are very variable, ranging from the Walker-Warburg phenotype (severe brain dysgenesis with associated hydrocephalus, and severe ocular anomalies) to the Fukuyama phenotype (with much less severe brain and ocular anomalies) to patients with findings limited to congenital muscular dystrophy, mental retardation, and cerebellar cysts (Topaloglu et al. 2003; Barkovich et al. 2012). In addition, MRI phenotypes vary, with some cobblestone malformations having an irregular, bumpy (microgyric-appearing) inner and outer cortical surface (Fig. 7A), whereas others have a rather smooth ("lissencephalic") subpial surface, resulting from columns of neurons extending perpendicular to the cortical surface for variable depths into the underlying white matter (Fig. 7B). This difference appears to be a result of the amount of tissue in the "extracortical 
A.J. Barkovich et al.
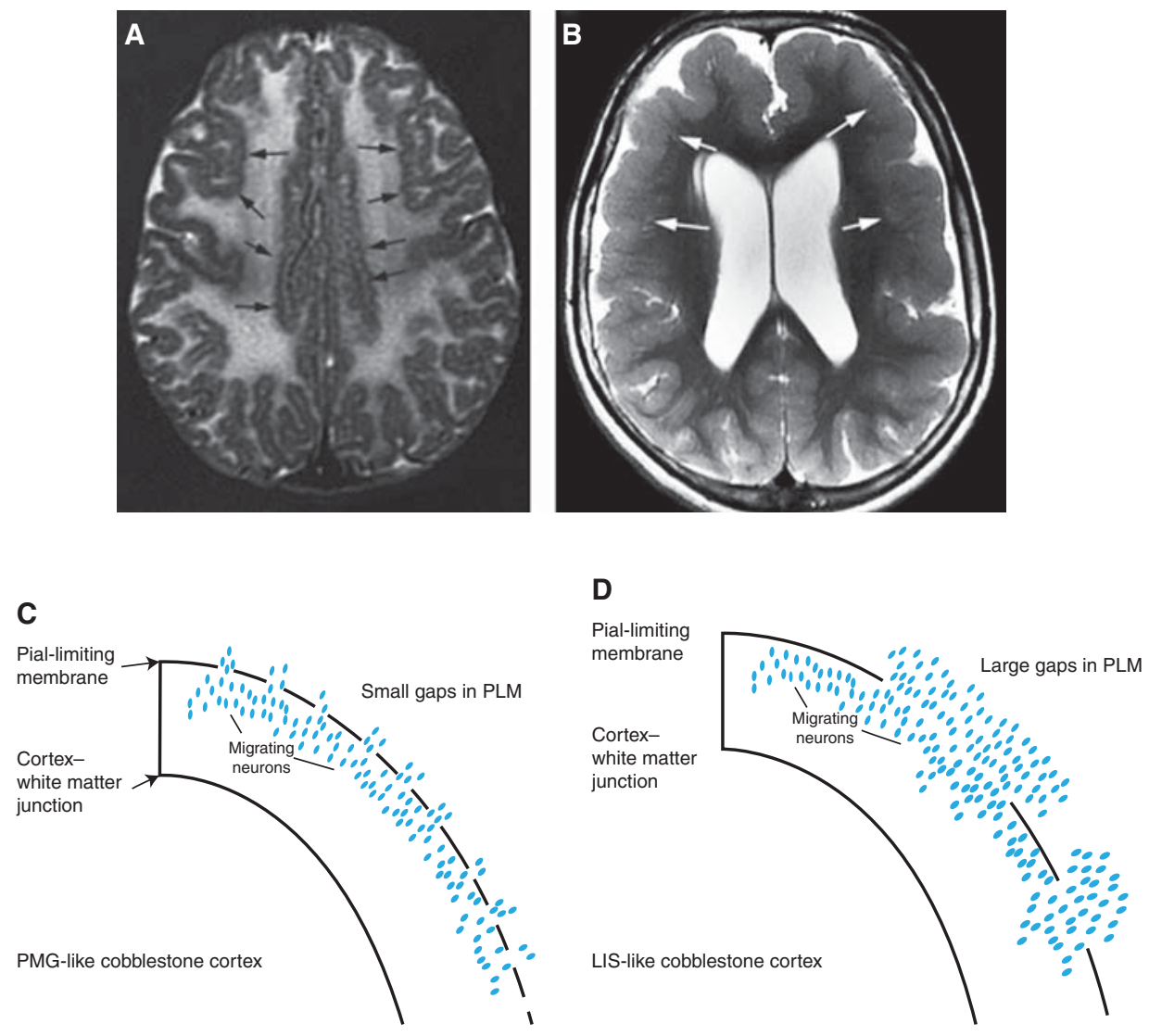

Figure 7. Cobblestone malformations. Phenotypes of cobblestone malformations vary with small, dysmorphic cerebella and brain stems (not shown) in addition to the cortical malformations. The latter may show $(A)$ a microgyric pattern (black arrows), or $(B)$ a pachygyric, lissencephalic-like pattern (white arrows). It is postulated that the former pattern results from $(C)$ migration of relatively few neurons through small gaps in the pial limiting membrane, while the latter results from $(D)$ larger gaps and greater number of neurons migrating into the subarachnoid space.

layer" (the name given to the cells that migrate through the gaps in the PLM and into the subarachnoid space), which is, in turn, related to the size of the gaps in the PLM (Fig. 7C,D) (Devisme et al. 2012). Although it is likely related to the lack of linkage of the RGCs to the PLM, the precise cause of the gaps in the PLM remains unknown. Moreover, many patients in this spectrum of disorders remain unclassified and much work remains: to define unknown RGC-PLM linkages and their molecular components, to determine why cortical malformations in some have an anterior-to-posterior gradient and others are predominantly posterior, to understand the cause of the associated myelination deficits, and to develop potential therapies.

\section{MALFORMATIONS SECONDARY TO ABNORMAL POSTMIGRATIONAL CORTICAL DEVELOPMENT}

\section{PMGs}

PMG is a term used to describe malformations characterized by an excessive number of small and prominent convolutions spaced out by shallow and enlarged sulci; the pathologic hallmark is fusion of the molecular layer of the cortex above the microgyri (Friede 1989; Jud- 
kins et al. 2011). It may develop nearly anywhere in the cerebral cortex, with many cases resulting from prenatal ischemic, teratogenic, or infectious brain injury (Friede 1989; Norman et al. 1995). PMG may be isolated or associated with other brain malformations, most commonly PNH (Wieck et al. 2005) or schizencephaly (Barkovich and Kjos 1992; Barkovich et al. 2012). Indeed, schizencephaly may be considered a severe variant of PMG, which is likely to be acquired (Barkovich and Kjos 1992; Barkovich et al. 2012), and is associated with young maternal age, absence of prenatal care, alcohol use, and non-CNS anomalies that are likely secondary to vascular disruption (Curry et al. 2005; Dies et al. 2013); genetic causes seem to be very rare. PMG is seen in a wide number of patterns and syndromes (Barkovich 2010; Leventer et al. 2010) and is associated with mutations in several genes (Guerrini and Parrini 2010). The spectrum of associated clinical manifestations is very wide, ranging from severe early-onset encephalopathy with spastic quadriparesis, profound retardation, and intractable epilepsy to normal individuals with selective impairment of higher-order neurological functions (Galaburda et al. 1985; Cohen et al. 1989). PMG syndromes (Barkovich et al. 1999) are based on lobar topography of the malformation and include bilateral perisylvian PMG (Kuzniecky et al. 1993a), bilateral frontal PMG (Guerrini et al. 2000), bilateral parasagittal parieto-occipital PMG (Guerrini et al. 1997), and multilobar PMG (Guerrini et al. 1998). Most cases of these disorders are sporadic, but some families have been reported. In particular, autosomal recessive bilateral frontoparietal PMG has also been described, but is currently considered to be a cobblestone malformation ( $\mathrm{Li}$ et al. 2008; Bahi-Buisson et al. 2010; Barkovich et al. 2012). In addition, some appear to have rather distinctive clinical manifestations, which seem to reflect the regions of the cerebrum affected.

The perisylvian region is, by far, the most common location for PMG (Hayashi et al. 2002; Leventer et al. 2010), and it is not surprising that "bilateral perisylvian PMG" is, by far, the most common bilateral PMG syndrome (Leventer et al. 2010). The affected cortex is sometimes restricted to the areas surrounding the sylvian fissures bilaterally, but may extend superiorly over the convexity, and anteriorly or posteriorly nearly as far as the frontal and occipital poles. Analysis of such cases shows a tapering of the PMG as the malformation extends away from the perisylvian region (Leventer et al. 2010). The medial surfaces of the cerebral hemispheres are rarely involved. More extensive involvement is associated with poorer motor and cognitive outcomes (Gropman et al. 1997; Clark et al. 2006). Some cases show marked asymmetry of involvement, with a striking $(80 \%)$ predisposition for the right hemisphere; these are frequently associated with deletions of chromosome 22q11.2 (Sztriha et al. 2004; Chang et al. 2006; Robin et al. 2006). A missense mutation of the SRPX2 gene at Xq22 was reported in an affected male, and this may explain the associated faciopharyngo-glosso-masticatory diplegia with dissociation of automatic (preserved) and voluntary (impaired) facial motility described in some affected patients (Guerrini et al. 1992; Kuzniecky et al. 1993a). Seizures are very common, typically beginning in the second half of the first decade, and are poorly controlled in $\sim 65 \%$; atypical absences, tonic or atonic drop attacks, and tonic-clonic seizures are most frequent, often occurring as Lennox-Gastaut-like syndromes. A minority has partial seizures, typically involving facial muscles (Guerrini et al. 1992; Kuzniecky et al. 1994; Gropman et al. 1997). Other forms of bilateral symmetrical PMG are much less common, have not been associated with specific genes or mutations, and will not be discussed. Unilateral PMG is a relatively frequent cause of epilepsy with continuous spikes and waves during sleep, which has a variable duration and consequences on cognitive abilities, but an invariably favorable seizure outcome (Guerrini et al. 1998).

PMG is poorly understood from a brain developmental perspective, partly because the term has been used imprecisely in the literature, and partly because many different processes can result in a thin cortex with many small sulci/ gyri: shunted brains of infants born with severe congenital hydrocephalus (stenogyria) (Miller et al. 2008), brains with defects in the PLM (cob- 
A.J. Barkovich et al.

blestone cortical malformations) (Bahi-Buisson et al. 2010; Devisme et al. 2012), ciliopathies (Giordano et al. 2009; Kheradmand Kia et al. 2012), tubulinopathies (Jaglin et al. 2009; Jansen et al. 2011; Cederquist et al. 2012; Guerrini et al. 2012; Romaniello et al. 2012), inborn errors of metabolism (Gressens et al. 2000; van Straaten et al.2005), formation of subcortical heterotopia (Barkovich 2000), and many others. Although it has become accepted that stenogyria and cobblestone cortex differ from "true" PMG, the many different types of irregular cerebral cortices that continue to be labeled as PMG cause considerable confusion and have resulted in some investigators creating a category of "PMG-like" malformations (Cushion et al. 2013). Unfortunately, the imaging characteristics of "true" PMG are difficult to determine because surgi$\mathrm{cal} /$ pathological correlation is very uncommon. Pathologists describe "true" PMG as showing cortical lamination defects, in contrast to "microgyria" or "polygyria," in which a normal sixlayer cortex persists (Friede 1989). Recent work has shown that the cortical lamination of PMG varies within patients; so-called "unlayered" (also called two-layer) PMG, classic four-layer PMG, and six-layer PMG (normal neocortical laminar pattern, but showing fusion of the molecular layer) may all be present in a single patient (Judkins et al. 2011). Moreover, neurons seem to be positioned in appropriate laminae, suggesting that $\mathrm{PMG}$ is not a migration disorder, but a postmigration disruption with the only defining characteristic being fusion of the molecular layer (Judkins et al. 2011). The challenge at this time would seem to be finding a means other than histology to accurately separate PMG from other types of microgyria to aid in classification and understanding of these many disorders. New MRI techniques show promise in this regard (Im et al. 2012).

\section{CONCLUSION}

MCDs are a fascinating, wide-ranging group of disorders, which are common causes of developmental delay and epilepsy. A focus on understanding the molecular pathways that are disturbed in these disorders will allow treatments to be developed, whereas, at the same time, improving our understanding of brain development.

\section{REFERENCES}

Al-Dosari MS, Shaheen R, Colak D, Alkuraya FS. 2010. Novel CENPJ mutation causes Seckel Syndrome. J Med Genet 47: 411-414.

Alkuraya FS, Cai X, Emery C, Mochida GH, Al-Dosari MS, Felie JM, Hill RS, Barry BJ, Partlow JN, Gascon GG, et al. 2011. Human mutations in NDE1 cause extreme microcephaly with lissencephaly. Am J Hum Genet 88: 536547.

Bahi-Buisson N, Poirier K, Boddaert N, Saillour Y, Castelnau L, Philip N, Buyse G, Villard L, Joriot S, Marret S, et al. 2008. Refinement of cortical dysgeneses spectrum associated with TUBA1A mutations. J Med Genet 45: 647653.

Bahi-Buisson N, Poirier K, Boddaert N, Fallet-Bianco C, Specchio N, Bertini E, Caglayan O, Lascelles K, Elie C, Rambaud J, et al. 2010. Gpr56-related bilateral frontoparietal polymicrogyria: Further evidence for an overlap with the cobblestone complex. Brain 133: 3194-3209.

Bahi-Buisson N, Souville I, Fourniol FJ, Toussaint A, Moores CA, Houdusse A, Lemaitre JY, Poirier K, Khalaf-Nazzal R, Hully M, et al. 2013. New insights into genotype-phenotype correlations for the doublecortinrelated lissencephaly spectrum. Brain 136: 223-244.

Bakircioglu M, Carvalho OP, Khurshid M, Cox JJ, Tuysuz B, Barak T, Yilmaz S, Caglayan O, Dincer A, Nicholas AK, et al. 2011. The essential role of centrosomal NDE1 in human cerebral cortex neurogenesis. Am J Hum Genet 88: 523-535.

Barak T, Kwan KY, Louvi A, Demirbilek V, Saygi S, Tüysüz B, Choi M, Boyac1 H, Doerschner K, Zhu Y, et al. 2011. Recessive LAMC3 mutations cause malformations of occipital cortical development. Nat Genet 43: 590-594.

Barkovich AJ. 1998. Neuroimaging manifestations and classification of congenital muscular dystrophies. AJNR Am J Neuroradiol 19: 1389-1396.

Barkovich AJ. 2000. Morphologic characteristics of subcortical heterotopia: MR imaging study. AJNR Am J Neuroradiol 21: 290-295.

Barkovich AJ. 2010. MRI analysis of sulcation morphology in polymicrogyria. Epilepsia 51: 17-22.

Barkovich AJ, Chuang SH. 1990. Unilateral megalencephaly: Correlation of MR imaging and pathologic characteristics. AJNR Am J Neuroradiol 11: 523-531.

Barkovich AJ, Kjos BO. 1992. Schizencephaly: Correlation of clinical findings with MR characteristics. AJNR Am J Neuroradiol 13: 85-94.

Barkovich AJ, Guerrini R, Battaglia G, Kalifa G, N'Guyen T, Parmeggiani A, Santucci M, Giovanardi-Rossi P, Granata T, D’Incerti L. 1994. Band heterotopia: Correlation of outcome with MR imaging parameters. Ann Neurol 36: 609-617.

Barkovich AJ, Kuzniecky RI, Dobyns WB, Jackson GD, Becker LE, Evrard P. 1996. A classification scheme for 
malformations of cortical development. Neuropediatrics 27: 59-63.

Barkovich AJ, Hevner R, Guerrini R. 1999. Syndromes of bilateral symmetrical polymicrogyria. AJNR Am J Neuroradiol 20: 1814-1821.

Barkovich AJ, Kuzniecky RI, Jackson GD, Guerrini R, Dobyns WB. 2001. Classification system for malformations of cortical development: Update 2001. Neurology 57: 2168-2178.

Barkovich AJ, Guerrini R, Kuzniecky RI, Jackson GD, Dobyns WB. 2012. A developmental and genetic classification for malformations of cortical development: Update 2012. Brain 135: 1348-1369.

Barone R, Aiello C, Race V, Morava E, Foulquier F, Riemersma M, Passarelli C, Concolino D, Carella M, Santorelli F, et al. 2012. DPM2-CDG: A muscular dystrophydystroglycanopathy syndrome with severe epilepsy. Ann Neurol 72: 550-558.

Beltran-Valero de Bernabe D, Voit T, Longman C, Steinbrecher A, Straub V, Yuva Y, Herrmann R, Sperner J, Korenke C, Diesen C, et al. 2004. Mutations in the FKRP gene can cause muscle-eye-brain disease and Walker-Warburg syndrome. J Med Genet 41: e61.

Bicknell LS, Bongers EM, Leitch A, Brown S, Schoots J, Harley ME, Aftimos S, Al-Aama JY, Bober M, Brown $\mathrm{PA}$, et al. 2011. Mutations in the pre-replication complex cause Meier-Gorlin syndrome. Nat Genet 43: 356-359.

Blümcke I, Thom M, Aronica E, Armstrong D, Vinters HV Palmini A, Jacques TS, Avanzini G, Barkovich AJ, Battaglia G, et al. 2011. The clinicopathologic spectrum of focal cortical dysplasias: A consensus classification proposed by an ad hoc Task Force of the ILAE Diagnostic Methods Commission. Epilepsia 52: 158-174.

Boer K, Troost D, Timmermans W, Van Rijen PC, Spliet WGM, Aronica E. 2010. PI3K-mTOR signaling and AMOG expression in epilepsy-associated glioneuronal tumors. Brain Pathol 20: 234-244.

Bolós V, Grego-Bessa J, de la Pompa JL. 2007. Notch signaling in development and cancer. Endocr Rev 28: 339363.

Bonneau D, Toutain A, Laquerrière A, Marret S, SaugierVeber P, Barthez M, Radi S, Biran-Mucignat V, Rodriguez D, Gélot A, et al. 2002. X-linked lissencephaly with absent corpus callosum and ambiguous genitalia (XLAG): Clinical, magnetic resonance imaging, and neuropathological findings. Ann Neurol 51: 340-349.

Boycott KM, Flavelle S, Bureau A, Glass HC, Fujiwara TM, Wirrell E, Davey K, Chudley AE, Scott JN, McLeod DR, et al. 2005. Homozygous deletion of the very low density lipoprotein receptor gene causes autosomal recessive cerebellar hypoplasia with cerebral gyral simplification. Am J Hum Genet 77: 477-483.

Braathen G, Theorell K. 1995. A general hospital population of childhood epilepsy. Acta Peediatrica 84: 1143 1146.

Bulteau C, Otsuki T, Delalande O. 2013. Epilepsy surgery for hemispheric syndromes in infants: Hemimegalencepahly and hemispheric cortical dysplasia. Brain Dev 35: $742-$ 747.

Cardoso C, Boys A, Parrini E, Mignon-Ravix C, McMahon JM, Khantane S, Bertini E, Pallesi E, Missirian C, Zuffardi O, et al. 2009. Periventricular heterotopia, mental retar- dation, and epilepsy associated with 5q14.3-q15 deletion. Neurology 72: 784-792.

Castiel A, Danieli MM, David A, Moshkovitz S, Aplan PD, Kirsch IR, Brandeis M, Krämer A, Izraeli S. 2011. The Stil protein regulates centrosome integrity and mitosis through suppression of Chfr. J Cell Sci 124: 532-539.

Cederquist GY, Luchniak A, Tischfield MA, Peeva M, Song Y, Menezes MP, Chan WM, Andrews C, Chew S, Jamieson RV, et al. 2012. An inherited TUBB2B mutation alters a kinesin-binding site and causes polymicrogyria, CFEOM and axon dysinnervation. Hum Mol Genet 21: 54845499.

Cellini E, Disciglio V, Novara F, Barkovich JA, Mencarelli MA, Hayek J, Renieri A, Zuffardi O, Guerrini R. 2012. Periventricular heterotopia with white matter abnormalities associated with 6p25 deletion. Am J Med Genet A 158A: 1793-1807.

Chang BS, Apse KA, Caraballo R, Cross JH, Mclellan A, Jacobson RD, Valente KD, Barkovich AJ, Walsh CA 2006. A familial syndrome of unilateral polymicrogyria affecting the right hemisphere. Neurology 66: 133-135.

Chen B, Tardell C, Higgins B, Packman K, Boylan JF, Niu H. 2012. BRAFV600E negatively regulates the AKT pathway in melanoma cell lines. PLoS ONE 7: e42598.

Chew S, Balasubramanian R, Chan WM, Kang PB, Andrews C, Webb BD, MacKinnon SE, Oystreck DT, Rankin J, Crawford TO, et al. 2013. A novel syndrome caused by the E410K amino acid substitution in the neuronal $\beta$ tubulin isotype 3. Brain 136: 522-535.

Clark M, Pitt M, Neville BG. 2006. Lower motor neuron involvement in perisylvian polymicrotyria. Dev Med Child Neurol 48: 842-846.

Cohen M, Campbell R, Yaghmai F. 1989. Neuropathological abnormalities in developmental dysphasia. Ann Neurol 25: $567-570$.

Colasante G, Collombat P, Raimondi V, Bonanomi D, Ferrai C, Maira M, Yoshikawa K, Mansouri A, Valtorta F, Rubenstein JL, et al. 2008. Arx is a direct target of Dlx2 and thereby contributes to the tangential migration of GABAergic interneurons. J Neurosci 28: 10674-10686.

Colasante G, Simonet JC, Calogero R, Crispi S, Sessa A, Cho G, Golden JA, Broccoli V. 2013. ARX regulates cortical intermediate progenitor cell expansion and upper layer neuron formation through repression of Cdknlc. Cereb Cortex 25: 322-335.

Colombo E, Collombat P, Colasante G, Bianchi M, Long J, Mansouri A, Rubenstein JLR, Broccoli V. 2007. Inactivation of Arx, the murine ortholog of the X-linked lissencephaly with ambiguous genitalia gene, leads to severe disorganization of the ventral telencephalon with impaired neuronal migration and differentiation. J Neurosci 27: 4786-4798.

Conti V, Carabalona A, Pallesi-Pocachard E, Parrini E, Leventer RJ, Buhler E, McGillivray G, Michel F, Striano P, Mei D, et al. 2013. Periventricular heterotopia in 6q terminal deletion syndrome: Role of the C6orf70 gene. Brain 136: 3378-3394.

Crino P. 2013. Evolving neurobiology of tuberous sclerosis complex. Acta Neuropathol 125: 317-332.

Crino PB, Aronica E, Baltuch G, Nathanson KL. 2010. Biallelic TSC gene inactivation in tuberous sclerosis complex. Neurology 74: 1716-1723. 
A.J. Barkovich et al.

Curry CJ, Lammer EJ, Nelson V, Shaw GM. 2005. Schizencephaly: Heterogeneous etiologies in a population of 4 million California births. Am J Med Genet A 137: 181189.

Cushion TD, Dobyns WB, Mullins JG, Stoodley N, Chung SK, Fry AE, Hehr U, Gunny R, Aylsworth AS, Prabhakar P, et al. 2013. Overlapping cortical malformations and mutations in TUBB2B and TUBA1A. Brain 136: $536-$ 548.

D’Agostino MD, Bastos A, Piras C, Bernasconi A, Grisar T, Tsur VG, Snipes J, Juhasz C, Chugani H, Guerrini R, et al. 2004. Posterior quadrantic dysplasia or hemi-hemimegalencephaly: A characteristic brain malformation. Neurology 62: 2214-2220.

Dambska M, Wisniewski K, Sher JH. 1983. Lissencephaly: Two distinct clinico-pathological types. Brain Dev 5:302310.

D’Arcangelo G, Miao GG, Chen SC, Soares HD, Morgan JI, Curran T. 1995. A protein related to extracellular matrix proteins deleted in the mouse mutant reeler. Nature 374: 719-723.

D’Arcangelo G, Nakajima K, Miyata T, Ogawa M, Mikoshiba $\mathrm{K}$, Curran T. 1997. Reelin is a secreted glycoprotein recognized by the Cr-50 monoclonal antibody. J Neurosci 17: $23-31$

Dastjerdi FV, Consalez GG, Hawkes R. 2012. Pattern formation during development of the embryonic cerebellum. Front Neuroanat 6: 10

de Bernabe DB, van Bokhoven H, van Beusekom E, Van den Akker W, Kant S, Dobyns WB, Cormand B, Currier S, Hamel B, Talim B, et al. 2003. A homozygous nonsense mutation in the Fukutin gene causes a Walker-Warburg syndrome phenotype. J Med Genet 40: 845-848.

Dent EW, Gupton SL, Gertler FB. 2011. The growth cone cytoskeleton in axon outgrowth and guidance. Cold Spring Harb Perspect Biol 3: a001800.

Desir J, Cassart M, David P, Van Bogaert P, Abramowicz M. 2008. Primary microcephaly with ASPM mutation shows simplified cortical gyration with anteroposterior gradient pre- and postnatally. Am J Med Genet A 146A: 14391443.

Devisme L, Bouchet C, Gonzalès M, Alanio E, Bazin A, Bessières $\mathrm{B}$, Bigi $\mathrm{N}$, Blanchet $\mathrm{P}$, Bonneau $\mathrm{D}$, Bonnières D, et al. 2012. Cobblestone lissencephaly: Neuropathological subtypes and correlations with genes of dystroglycanopathies. Brain 135: 469-482.

de Wit M, Lequin M, de Coo I, Brusse E, Halley D, van de Graaf R, Schot R, Verheijen FS, Mancini G. 2008. Cortical brain malformations: Effect of clinical, neuroradiological, and modern genetic classification. Arch Neurol 65: 358-366.

Dies KA, Bodell A, Hisama FM, Guo C-Y, Barry B, Chang BS, Barkovich AJ, Walsh CA. 2013. Schizencephaly: Association with young maternal age, alcohol use, and lack of prenatal care. J Child Neurol 28: 198-203.

Di Rocco F, Novegno F, Tamburrini G, Iannelli A. 2001. Hemimegalencephaly involving the cerebellum. Pediatr Neurosurg 35: 274-276.

Di Rosa G, Messina S, D’Amico A, Bertini E, Pustorino G, Spanò M, Tortorella G. 2011. A new form of $\alpha$-dystroglycanopathy associated with severe drug-resistant epi- lepsy and unusual EEG features. Epileptic Disord 13: 259-262.

Dobyns WB, Kirkpatrick JB, Hittner HM, Roberts RM, Kretzer FL. 1985. Syndromes with lissencephaly: II. Walker-Warburg and cerebro-occular-muscular syndromes and a new syndrome with type II lissencephaly. Am J Med Genet 22: 157-195.

Dobyns W, Reiner O, Carrozzo R, Ledbetter D. 1993. Lissencephaly: A human brain malformation associated with deletion of the LIS1 gene located at chromosome 17p13. J Am Med Assoc 270: 2838-2842.

Dubeau F, Tampieri D, Lee N, Andermann E, Carpenter S, Leblanc R, Olivier A, Radtke R, Villemure JG, Andermann F. 1995. Periventricular and subcortical nodular heterotopia. A study of 33 patients. Brain 1273-1287.

Dubeau F, Li LM, Bastos A, Andermann E, Andermann F. 1999. Periventricular nodular heteropia: Further delineation of the clinical syndromes. In Abnormal cortical development and epilepsy, pp. 203-217. Lohn Libbey, London.

Easton RM, Cho H, Roovers K, Shineman DW, Mizrahi M, Forman MS, Lee VM, Szabolcs M, de Jong R, Oltersdorf T, et al. 2005. Role for Akt3/protein kinase B $\gamma$ in attainment of normal brain size. Mol Cell Biol 25: 18691878.

Faustino A, Couto JP, Pópulo H, Rocha AS, Pardal F, Cameselle-Teijeiro JM, Lopes JM, Sobrinho-Simões M, Soares P. 2012. mTOR pathway overactivation in BRAF mutated papillary thyroid carcinoma. J Clin Endocrinol Metab 97: E1139-E1149.

Ferland RJ, Guerrini R. 2009. Nodular heterotopia is built upon layers. Neurology 73: 742-743.

Ferland R, Gaitanis J, Apse K, Tantravahi U, Walsh CA, Sheen V. 2006. Periventricular nodular heterotopia and Williams syndrome. Am J Med Genet A 140: 1305-1311.

Flores-Sarnat L, Sarnat H, Davila-Gutierrez G, Alvarez A. 2003. Hemimegalencephaly: Part 2. Neuropathology suggests a disorder of cellular lineage. J Child Neurol 18: 776-785.

Forman MS, Squier W, Dobyns WB, Golden JA. 2005. Genotypically defined lissencephalies show distinct pathologies. J Neuropathol Exp Neurol 64: 847-857.

Fox JW, Lamperti ED, Ekşioğlu YZ, Hong SE, Feng Y, Graham DA, Scheffer IE, Dobyns WB, Hirsch BA, Radtke RA, et al. 1998. Mutations in filamin 1 prevent migration of cerebral cortical neurons in human periventricular heterotopia. Neuron 21: 1315-1325.

Frater JL, Prayson RA, Morris HH III, Bingaman WE. 2000. Surgical pathologic findings of extratemporal-based intractable epilepsy: A study of 133 consecutive resections. Arch Pathol Lab Med 124: 545-549.

Friede RL. 1989. Developmental neuropathology, 2nd ed. Springer, Berlin.

Fulp CT, Cho G, Marsh ED, Nasrallah IM, Labosky PA, Golden JA. 2008. Identification of Arx transcriptional targets in the developing basal forebrain. Hum Mol Genet 17: $3740-3760$.

Galaburda AM, Sherman GF, Rosen GD, Aboitiz F, Geschwind N. 1985. Developmental dyslexia: Four consecutive patients with cortical anomalies. Ann Neurol 18: 222 233. 
Garbelli R, Rossini L, Moroni RF, Watakabe A, Yamamori T, Tassi L, Bramerio M, Russo GL, Frassoni C, Spreafico R. 2009. Layer-specific genes reveal a rudimentary laminar pattern in human nodular heterotopia. Neurology 73: 746-753.

Giordano L, Vignoli A, Pinelli L, Brancati F, Accorsi P, Faravelli F, Gasparotti R, Granata T, Giaccone G, Inverardi F, et al. 2009. Joubert syndrome with bilateral polymicrogyria: Clinical and neuropathological findings in two brothers. Am J Med Genet 149A: 1511-1515.

Glass HC, Boycott KM, Adams C, Barlow K, Scott JN, Chudley AE, Fujiwara TM, Morgan K, Wirrell E, McLeod DR. 2005. Autosomal recessive cerebellar hypoplasia in the Hutterite population. Dev Med Child Neurol 47: 691695.

Gleeson JG, Allen KM, Fox JW, Lamperti ED, Berkovic S, Scheffer I, Cooper EC, Dobyns WB, Minnerath SR, Ross ME, et al. 1998. Doublecortin, a brain-specific gene mutated in human X-linked lissencephaly and double cortex syndrome, encodes a putative signaling protein. Cell 92: $63-72$.

González G, Vedolin L, Barry B, Poduri A, Walsh C, Barkovich AJ. 2013. Location of periventricular nodular heterotopia is related to the malformation phenotype on MRI. AJNR Am J Neuroradiol 34: 877-883.

Gressens P, Baes M, Leroux P, Lombet A, Van Veldhoven P, Janssen A, Vamecq J, Marret S, Evrard P. 2000. Neuronal migration disorder in Zellweger mice is secondary to glutamate receptor dysfunction. Ann Neurol 48: $336-$ 343.

Gropman AL, Barkovich AJ, Vezina LG, Conry JA, Dubovsky EC, Packer RJ. 1997. Pediatric congenital bilateral perisylvian syndrome: Clinical and MRI features in 12 patients. Neuropediatrics 28: 198-203.

Guerrini R. 2006. Epilepsy in children. Lancet 367: 499-524.

Guerrini R, Parrini E. 2010. Neuronal migration disorders. Neurobiol Dis 38: 154-166.

Guerrini R, Dravet C, Raybaud C, Roger J, Bureau M, Battaglia A, Livet MO, Colicchio G, Robain O. 1992. Neurological findings and seizure outcome in children with bilateral opercular macrogyric-like changes detected by MRI. Dev Med Child Neurol 34: 694-705.

Guerrini R, Dubeau F, Dulac O, Barkovich AJ, Kuzniecky R, Fett C, Jones-Gottman M, Canapicchi R, Cross H, et al. 1997. Bilateral parasagittal parietooccipital polymicrogyria and epilepsy. Ann Neurol 41: 65-73.

Guerrini R, Genton P, Bureau M, Parmeggiani A, Salas-Puig X, Santucci M, Bonanni P, Ambrosetto G, Dravet C. 1998. Multilobar polymicrogyria, intractable drop attack seizures, and sleep-related electrical status epilepticus. Neurology 51: 504-512.

Guerrini R, Barkovich A, Sztriha L, Dobyns W. 2000. Bilateral frontal polymicrogyria. Neurology 54: 909-913.

Guerrini R, Mei D, Cordelli DM, Pucatti D, Franzoni E, Parrini E. 2012. Symmetric polymicrogyria and pachygyria associated with Tubb2b mutations. Eur J Hum Genet 20: 995-998.

Haas C, Frotscher M. 2010. Reelin deficiency causes granule cell dispersion in epilepsy. Exp Brain Res 200: 141149.
Hayashi N, Tsutsumi Y, A Barkovich AJ. 2002. Polymicrogyria without porencephaly/schizencephaly. MRI analysis of the spectrum and the prevalence of macroscopic findings in the clinical population. Neuroradiology 44: 647-655.

Hong SE, Shugart YY, Huang DT, Al Shahwan S, Grant PE, Hourihane JOB, Martin NDT, Walsh CA. 2000. Autosomal recessive lissencephaly with cerebellar hypoplasia is associated with human RELN gene mutations. Nat Genet 26: 93-96.

Hourihane J, Bennett C, Chaudhuri R, Robb S, Martin N. 1993. A sibship with a neuronal migration defect, cerebellar hypoplasia and congenital lymphedema. Neuropediatrics 24: $43-46$.

Huang J, Roberts AJ, Leschziner AE, Reck-Peterson SL. 2012. Lis1 acts as a "clutch" between the ATPase and microtubule-binding domains of the dynein motor. Cell 150: 975-986.

Im K, Pienaar R, Paldino MJ, Gaab N, Galaburda AM, Grant PE. 2012. Quantification and discrimination of abnormal sulcal patterns in polymicrogyria. Cereb Cortex 23: 3007-3015.

Jaglin XH, Poirier K, Saillour Y, Buhler E, Tian G, BahiBuisson N, Fallet-Bianco C, Phan-Dinh-Tuy F, Kong XP, Bomont P, et al. 2009. Mutations in the $\beta$-tubulin gene TUBB2B result in asymmetrical polymicrogyria. Nat Genet 41: 746-752.

Jansen AC, Oostra A, Desprechins B, De Vlaeminck Y, Verhelst H, Régal L, Verloo P, Bockaert N, Keymolen K, Seneca $S$, et al. 2011. TUBA1A mutations: From isolated lissencephaly to familial polymicrogyria. Neurology 76: 988-992.

Judkins AR, Martinez D, Ferreira P, Dobyns WB, Golden JA. 2011. Polymicrogyria includes fusion of the molecular layer and decreased neuronal populations but normal cortical laminar organization. J Neuropathol Exp Neurol 70: $438-443$.

Kalay E, Yigit G, Aslan Y, Brown KE, Pohl E, Bicknell LS, Kayserili H, Li Y, Tuysuz B, Nurnberg G, et al. 2011. Cep152 is a genome maintenance protein disrupted in Seckel syndrome. Nat Genet 43: 23-26.

Kato M, Das S, Petras K, Kitamura K, Morohashi K, Abuelo DN, Barr M, Bonneau D, Brady AF, Carpenter NJ, et al. 2004. Mutations of ARX are associated with striking pleiotropy and consistent genotype-phenotype correlation. Hum Mutat 23: 147-159.

Kheradmand Kia S, Verbeek E, Engelen E, Schot R, Poot RA, de Coo IF, Lequin MH, Poulton CJ, Pourfarzad F, Grosveld FG, et al. 2012. RTTN mutations link primary cilia function to organization of the human cerebral cortex. Am J Hum Genet 91: 533-540.

Kitamura K, Yanazawa M, Sugiyama N, Miura H, IizukaKogo A, Kusaka M, Omichi K, Suzuki R, Kato-Fukui Y, Kamiirisa K, et al. 2002. Mutation of ARX causes abnormal development of forebrain and testes in mice and Xlinked lissencephaly with abnormal genitalia in humans. Nat Genet 32: 359-369.

Koelsche C, Wöhrer A, Jeibmann A, Schittenhelm J, Schindler G, Preusser M, Lasitschka F, Deimling A, Capper D. 2013. Mutant BRAF V600E protein in ganglioglioma is predominantly expressed by neuronal tumor cells. Acta Neuropathol 125: 891-900. 
A.J. Barkovich et al.

Kuijpers M, Hoogenraad CC. 2011. Centrosomes, microtubules and neuronal development. Mol Cell Neurosci 48: 349-358.

Kumar RA, Pilz DT, Babatz TD, Cushion TD, Harvey K, Topf M, Yates L, Robb S, Uyanik G, Mancini GM, et al. 2010. TUBA1A mutations cause wide spectrum lissencephaly (smooth brain) and suggest that multiple neuronal migration pathways converge on $\alpha$ tubulins. Hum Mol Genet 19: 2817-2827.

Kurek KC, Luks VL, Ayturk UM, Alomari AI, Fishman SJ, Spencer SA, Mulliken JB, Bowen ME, Yamamoto GL, Kozakewich HP, et al. 2012. Somatic mosaic activating mutations in PIK3CA cause CLOVES syndrome. Am J Hum Genet 90: 1108-1115.

Kuzniecky R, Andermann F, Guerrini R. 1993a. Congenital bilateral perisylvian syndrome: Study of 31 patients. The CBPS Multicenter Collaborative Study. Lancet 341: 608612 .

Kuzniecky R, Murro A, King D, Morawetz R, Smith J, Powers R, Yaghmai F, Faught E, Gallagher B, Snead OC. 1993b. Magnetic resonance imaging in childhood intractable partial epilepsy: Pathologic correlations. Neurology 43: 681-687.

Kuzniecky R, Andermann F, Guerrini R. 1994. Infantile spasms: An early epileptic manifestation in some patients with the congenital bilateral perisylvian syndrome. $J$ Child Neurol 9: 420-423.

Labelle-Dumais C, Dilworth DJ, Harrington EP, de Leau M, Lyons D, Kabaeva Z, Manzini MC, Dobyns WB, Walsh CA, Michele DE, et al. 2011. COL4A1 mutations cause ocular dysgenesis, neuronal localization defects, and myopathy in mice and Walker-Warburg syndrome in humans. PLoS Genet 7: e1002062.

Lakomá J, Garcia-Alonso L, Luque JM. 2011. Reelin sets the pace of neocortical neurogenesis. Development 138: 5223-5234.

Laplante M, Sabatini DM. 2013. Regulation of mTORC1 and its impact on gene expression at a glance. J Cell Sci 126: $1713-1719$.

Lecourtois M, Poirier K, Friocourt G, Jaglin X, Goldenberg A, Saugier-Veber P, Chelly J, Laquerrière A. 2010. Human lissencephaly with cerebellar hypoplasia due to mutations in TUBA1A: Expansion of the foetal neuropathological phenotype. Acta Neuropathol 119: 779-789.

Lee JH, Huynh M, Silhavy JL, Kim S, Dixon-Salazar T, Heiberg A, Scott E, Bafna V, Hill KJ, Collazo A, et al. 2012. De novo somatic mutations in components of the PI3KAKT3-mTOR pathway cause hemimegalencephaly. Nat Genet 44: 941-945.

Leventer RJ, Jansen A, Pilz DT, Stoodley N, Marini C, Dubeau F, Malone J, Mitchell LA, Mandelstam S, Scheffer IE, et al. 2010. Clinical and imaging heterogeneity of polymicrogyria: A study of 328 patients. Brain 133: 14151427.

Li S, Jin Z, Koirala S, Bu L, Xu L, Hynes RO, Walsh CA, Corfas G, Piao X. 2008. GPR56 regulates pial basement membrane integrity and cortical lamination. J Neurosci 28: 5817-5826.

Lim KC, Crino PB. 2013. Focal malformations of cortical development: New vistas for molecular pathogenesis. Neuroscience 252: 262-276.
Luo R, Jeong SJ, Jin Z, Strokes N, Li S, Piao X. 2011. G protein-coupled receptor 56 and collagen III, a receptor-ligand pair, regulates cortical development and lamination. Proc Natl Acad Sci 108: 12925-12930.

Luo R, Jin Z, Deng Y, Strokes N, Piao X. 2012. Diseaseassociated mutations prevent GPR56-collagen III interaction. PLoS ONE 7: e29818.

Mahmood S, Ahmad W, Hassan MJ. 2011. Autosomal recessive primary microcephaly $(\mathrm{MCPH})$ : Clinical manifestations, genetic heterogeneity and mutation continuum. Orphanet J Rare Dis 6: 39.

Mai R, Tassi L, Cossu M, Francione S, Lo Russo G, Garbelli R, Ferrario A, Galli C, Taroni F, Citterio A, et al. 2003. A neuropathological, stereo-EEG, and MRI study of subcortical band heterotopia. Neurology 60: 18341838.

Mandelstam SA, Leventer RJ, Sandow A, McGillivray G, van Kogelenberg M, Guerrini R, Robertson S, Berkovic SF, Jackson GD, Scheffer IE. 2013. Bilateral posterior periventricular nodular heterotopia: A recognizable cortical malformation with a spectrum of associated brain abnormalities. AJNR Am J Neuroradiol 34: 432-438.

Marin O, Valiente M, Ge X, Tsai LH. 2010. Guiding neuronal cell migrations. Cold Spring Harb Perspect Biol 2: a001834.

Martin PT. 2005. The dystroglycanopathies: The new disorders of O-linked glycosylation. Semin Pediatr Neurol 12: $152-158$.

McKenney RJ, Vershinin M, Kunwar A, Vallee RB, Gross SP. 2010. LIS1 and NudE induce a persistent dynein forceproducing state. Cell 141: 304-314.

Meseke M, Cavus E, Forster E. 2013a. Reelin promotes microtubule dynamics in processes of developing neurons. Histochem Cell Biol 139: 283-297.

Meseke M, Rosenberger G, Forster E. 2013b. Reelin and the $\mathrm{Cdc42/Racl}$ guanine nucleotide exchange factor $\alpha \mathrm{PIX} /$ Arhgef6 promote dendritic Golgi translocation in hippocampal neurons. Eur J Neurosci 37: 1404-1412.

Miller E, Widjaja E, Blaser S, Dennis M, Raybaud C. 2008. The old and the new: Supratentorial MR findings in Chiari II malformation. Child's Nerv Syst 24: 563-575.

Mischel PS, Nguyen LP, Vinters HV. 1995. Cerebral cortical dysplasia associated with pediatric epilepsy. Review of neuropathologic features and proposal for a grading system. J Neuropath Exp Neurol 54: 137-153.

Miyata R, Hayashi M, Miyai K, Akashi T, Kato M, Kohyama J. 2009. Analysis of the hypothalamus in a case of Xlinked lissencephaly with abnormal geneitalia (XLAG). Brain Dev 31: 456-460.

Myshrall TD, Moore SA, Ostendorf AP, Satz JS, Kowalczyk T, Nguyen H, Daza RA, Lau C, Campbell KP, Hevner RF 2012. Dystroglycan on radial glia end feet is required for pial basement membrane integrity and columnar organization of the developing cerebral cortex. J Neuropath Exp Neurol 71: 1047-1063.

Nakahashi M, Sato N, Yagishita A, Ota M, Saito Y, Sugai K, Sasaki M, Natsume J, Tsushima Y, Amanuma M, et al. 2009. Clinical and imaging characteristics of localized megalencephaly: A retrospective comparison of diffuse hemimegalencephaly and multilobar cortical dysplasia. Neuroradiology 51: 821-830. 
Neal J, Apse K, Sahin M, Walsh CA, Sheen VL. 2006. Deletion of chromosome $1 \mathrm{p} 36$ is associated with periventricular nodular heterotopia. Am J Med Genet A 140: $1692-$ 1695.

Nelligan A, Sander JW. 2011. Premature mortality in epilepsy: Is it preventable? Exp Rev Neurother 11: 767-770.

Ngugi AK, Kariuki SM, Bottomley G, Kleinschmidt I, Sander JW, Newton CR. 2011. Incidence of epilepsy: A systematic review and meta-analysis. Neurology 77: 1005-1012.

Norman MG, McGillivray BC, Kalousek DK, Hill A, Poskitt KJ. 1995. Congenital malformations of the brain: Pathologic, embryologic, clinical, radiologic and genetic aspects. Oxford University Press, Oxford.

Odabasi Z, Demikaya S, Gokcil Z, Atilla S, Vural O, Yardim M. 1997. Spect and MRI findings in a case of extensive neuronal migration disorder. Clin Neurol Neurosurg 99: 276-279.

Okazaki S, Ohsawa M, Kuki I, Kawawaki H, Koriyama T, Ri S, Ichiba H, Hai E, Inoue T, Nakamura H, et al. 2008 Aristaless-related homeobox gene disruption leads to abnormal distribution of GABAergic interneurons in human neocortex: Evidence based on a case of X-linked lissencephaly with abnormal genitalia (XLAG). Acta Neuropathol 116: 453-462.

Orlova KA, Tsai V, Baybis M, Heuer GG, Sisodiya S, Thom M, Strauss K, Aronica E, Storm PB, Crino PB. 2010. Early progenitor cell marker expression distinguishes type II from type I focal cortical dysplasias. J Neuropathol Exp Neurol 69: 850-863.

Pasquier B, Péoc'H M, Fabre-Bocquentin B, Bensaadi L, Pasquier D, Hoffmann D, Kahane P, Tassi L, Le Bas JF Benabid AL. 2002. Surgical pathology of drug-resistant partial epilepsy. A 10-year-experience with a series of 327 consecutive resections. Epileptic Disord 4: 99-119.

Passemard S, Titomanlio L, Elmaleh M, Afenjar A, Alessandri JL, Andria G, de Villemeur TB, Boespflug-Tanguy O, Burglen L, Del Giudice E, et al. 2009. Expanding the clinical and neuroradiologic phenotype of primary microcephaly due to ASPM mutations. Neurology 73: 962 969.

Pisano T, Barkovich AJ, Leventer RJ, Squier W, Scheffer IE, Parrini E, Blaser S, Marini C, Robertson S, Tortorella G, et al. 2012. Peritrigonal and temporo-occipital heterotopia with corpus callosum and cerebellar dysgenesis. Neurology 79: 1244-1251.

Poduri A, Evrony GD, Cai X, Elhosary PC, Beroukhim R, Lehtinen MK, Hills LB, Heinzen EL, Hill A, Hill RS, et al. 2012. Somatic activation of AKT3 causes hemispheric developmental brain malformations. Neuron 74: 41-48.

Poduri A, Evrony GD, Cai X, Walsh CA. 2013. Somatic mutation, genomic variation, and neurological disease. Science 341: 1237758.

Poirier K, Keays DA, Francis F, Saillour Y, Bahi N, Manouvrier S, Fallet-Bianco C, Pasquier L, Toutain A, Tuy FP, et al. 2007. Large spectrum of lissencephaly and pachygyria phenotypes resulting from de novo missense mutations in tubulin $\alpha 1$ A (TUBA1A). Hum Mutat 28: 1055-1064.

Poirier K, Saillour Y, Bahi-Buisson N, Jaglin XH, FalletBianco C, Nabbout R, Castelnau-Ptakhine L, Roubertie A, Attie-Bitach T, Desguerre I, Genevieve D, et al. 2010.
Mutations in the neuronal $\beta$-tubulin subunit TUBB3 result in malformation of cortical development and neuronal migration defects. Hum Mol Genet 19: 44624473.

Poirier K, Saillour Y, Fourniol F, Francis F, Souville I, Valence S, Desguerre I, Marie Lepage J, Boddaert N, Line Jacquemont M, et al. 2012. Expanding the spectrum of TUBA1A-related cortical dysgenesis to Polymicrogyria. Eur J Hum Genet 21: 381-385.

Poirier K, Lebrun N, Broix L, Tian G, Saillour Y, Boscheron C, Parrini E, Valence S, Pierre BS, Oger M, et al. 2013. Mutations in TUBG1, DYNC1H1, KIF5C and KIF2A cause malformations of cortical development and microcephaly. Nat Genet 45: 639-647.

Prabowo AS, Anink JJ, Lammens M, Nellist M, van den Ouweland AMW, Adle-Biassette H, Sarnat HB, FloresSarnat L, Crino PB, Aronica E. 2013. Fetal brain lesions in tuberous sclerosis complex: TORC1 activation and inflammation. Brain Pathol 23: 45-59.

Preul MC, Leblanc R, Cendes F, Dubeau F, Reutens D, Spreafico R, Battaglia G, Avoli M, Langevin P, Arnold DL, et al. 1997. Function and organization in dysgenetic cortex. Case report. J Neurosurg 87: 113-121.

Qin W, Chan JA, Vinters HV, Mathern GW, Franz DN, Taillon BE, Bouffard P, Kwiatkowski DJ. 2010. Analysis of TSC cortical tubers by deep sequencing of TSC1, TSC2 and KRAS demonstrates that small second-hit mutations in these genes are rare events. Brain Pathol 20: $1096-$ 1105.

Radmanesh F, Caglayan AO, Silhavy JL, Yilmaz C, Cantagrel V, Omar T, Rosti B, Kaymakcalan H, Gabriel S, Li M, et al. 2013. Mutations in LAMB1 cause cobblestone brain malformation without muscular or ocular abnormalities. Am J Hum Genet 92: 468-474.

Radner S, Banos C, Bachay G, Li YN, Hunter DD, Brunken WJ, Yee KT. 2013. B2 and Г3 laminins are critical cortical basement membrane components: Ablation of LAMB2 and LAMC3 genes disrupts cortical lamination and produces dysplasia. Dev Neurobiol 73: 209-229.

Ramocki MB, Bartnik M, Szafranski P, Kolodziejska KE, Xia Z, Bravo J, Miller GS, Rodriguez DL, Williams CA, Bader PI, et al. 2010. Recurrent distal 7q11.23 deletion including HIP1 and YWHAG identified in patients with intellectual disabilities, epilepsy, and neurobehavioral problems. Am J Hum Genet 87: 857-865.

Richardson MP, Koepp MJ, Brooks DJ, Coull JT, Grasby P, Fish DR, Duncan JS. 1998. Cerebral activation in malformations of cortical development. Brain 121: 12951304.

Riviere JB, Mirzaa GM, O'Roak BJ, Beddaoui M, Alcantara D, Conway RL, St-Onge J, Schwartzentruber JA, Gripp KW, Nikkel SM, et al. 2012. De novo germline and postzygotic mutations in AKT3, PIK3R2 and PIK3CA cause a spectrum of related megalencephaly syndromes. $\mathrm{Nat} \mathrm{Ge}$ net 44: 934-940.

Robin N, Taylor C, McDonald-McGinn D, Zackai E, Bingham P, Collins K, Earl D, Gill D, Granata T, Guerrini R, et al. 2006. Polymicrogyria and deletion 22Q11.2 syndrome: Window to the etiology of a common cortical malformation. Am J Med Genet A 140: $2416-2425$. 
A.J. Barkovich et al.

Romaniello R, Tonelli A, Arrigoni F, Baschirotto C, Triulzi F, Bresolin N, Bassi MT, Borgatti R. 2012. A novel mutation in the $\beta$-tubulin gene TUBB2B associated with complex malformation of cortical development and deficits in axonal guidance. Dev Med Child Neurol 54: $765-769$.

Saillour Y, Broix L, Bruel-Jungerman E, Lebrun N, Muraca G, Rucci J, Poirier K, Belvindrah R, Francis F, Chelly J. 2013. $\beta$ Tubulin isoforms are not interchangeable for rescuing impaired radial migration due to Tubb3 knockdown. Hum Mol Genet 23: 1516-1526.

Scherer C, Schuele S, Minotti L, Chabardes S, Hoffmann D, Kahane P. 2005. Intrinsic epileptogenicity of an isolated periventricular nodular heterotopia. Neurology 65: $495-$ 496.

Sekine K, Kawauchi T, Kubo K, Honda T, Herz J, Hattori M Kinashi T, Nakajima K. 2012. Reelin controls neuronal positioning by promoting cell-matrix adhesion via inside-out activation of integrin $\alpha 5 \beta 1$. Neuron 76: $353-$ 369.

Sener R. 1997. MR demonstration of cerebral hemimegalencephaly associated with cerebellar involvement (total hemimegalencephaly). Comput Med Imaging Graph 21: 201-204.

Sheen VL. 2012. Periventricular heterotopia: Shuttling of proteins through vesicles and actin in cortical development and disease. Scientifica 2012: 480129.

Sheen V, Wheless J, Bodell A, Braverman E, Cotter P, Rauen $\mathrm{K}$, Glenn O, Weisinger K, Packman S, Walsh CA, et al. 2003. Periventricular heterotopia associated with chromosome 5p anomalies. Neurology 60: 1033-1036.

Sheen VL, Ganesh VS, Topcu M, Sebire G, Bodell A, Hill RS, Grant PE, Shugart YY, Imitola J, Khoury SJ, et al. 2004. Mutations in ARFGEF2 implicate vesicle trafficking in neural progenitor proliferation and migration in the human cerebral cortex. Nat Genet 36: 69-76.

Sherr CJ, Roberts JM. 1999. CDK inhibitors: Positive and negative regulators of $\mathrm{G}_{1}$-phase progression. Genes Dev 13: $1501-1512$.

Shiba N, Daza R, Shaffer L, Barkovich A, Dobyns W, Hevner R. 2013. Neuropathology of brain and spinal malformations in a case of monosomy 1p36. Acta Neuropathol Commun 1: 45.

Splinter D, Razafsky DS, Schlager MA, Serra-Marques A, Grigoriev I, Demmers J, Keijzer N, Jiang K, Poser I, Hyman AA, et al. 2012. BICD2, Dynactin, and LIS1 cooperate in regulating dynein recruitment to cellular structures. Mol Biol Cell 23: 4226-4241.

Stromme P, Mangelsdorf ME, Scheffer IE, Gecz J. 2002. Infantile spasms, dystonia, and other X-linked phenotypes caused by mutations in aristaless related homeobox gene, ARX. Brain Dev 24: 266-268.

Sztriha L, Guerrini R, Harding B, Stewart F, Chelloug N, Johansen JG. 2004. Clinical, MRI, and pathological features of polymicrogyria in chromosome 22q11 deletion syndrome. Am J Med Genet 127A: 313-317.

Tang CJ, Fu RH, Wu KS, Hsu WB, Tang TK. 2009. CPAP is a cell-cycle regulated protein that controls centriole length. Nat Cell Biol 11: 825-831.

Tassi L, Colombo N, Garbelli R, Francione S, Lo Russo G, Mai R, Cardinale F, Cossu M, Ferrario A, Galli C, et al. 2002. Focal cortical dysplasia: Neuropathological sub- types, EEG, neuroimaging and surgical outcome. Brain 125: $1719-1732$.

Tassi L, Colombo N, Cossu M, Mai R, Francione S, Lo Russo G, Galli C, Bramerio M, Battaglia G, Garbelli R, et al. 2005. Electroclinical, MRI and neuropathological study of 10 patients with nodular heterotopia, with surgical outcomes. Brain 128: 321-337.

Thoreen CC, Chantranupong L, Keys HR, Wang T, Gray NS, Sabatini DM. 2012. A unifying model for mTORC1mediated regulation of mRNA translation. Nature 485: $109-113$.

Thornton GK, Woods CG. 2009. Primary microcephaly: Do all roads lead to Rome? Trends Genet 25: 501-510.

Tischfield MA, Baris HN, Wu C, Rudolph G, Van Maldergem L, He W, Chan WM, Andrews C, Demer JL, Roberson RL, et al. 2010. Human TUBB3 mutations perturb microtubule dynamics, kinesin interactions, and axon guidance. Cell 140: 74-87.

Tokuda S, Mahaffey CL, Monks B, Faulkner CR, Birnbaum MJ, Danzer SC, Frankel WN. 2011. A novel AKT3 mutation associated with enhanced kinase activity and seizure susceptibility in mice. Hum Mol Genet 20: 988 999.

Topaloglu H, Brockington M, Yuva Y, Talim B, Haliloglu G, Blake DJ, Torelli S, Brown SC, Muntoni F. 2003. FKRP gene mutations cause congenital muscular dystrophy, mental retardation, and cerebellar cysts. Neurology 60: 988-992.

Toyo-oka K, Shionoya A, Gambello MJ, Cardoso C, Leventer R, Ward HL, Ayala R, Tsai LH, Dobyns W, Ledbetter D, et al. 2003. 14-3-3e is important for neuronal migration by binding to NUDEL: A molecular explanation for Miller-Dieker syndrome. Nat Genet 34: $274-$ 285.

Tsai V, Parker WE, Orlova KA, Baybis M, Chi AW, Berg BD, Birnbaum JF, Estevez J, Okochi K, Sarnat HB, et al. 2012. Fetal brain mTOR signaling activation in tuberous sclerosis complex. Cereb Cortex 24: 315-327.

Van der Knaap MS, Smit LME, Barth PG, Catsman-Berrevoets $\mathrm{CE}$, Brouwer OF, Begeer JH, de Coo IFM, Valk J. 1997. Magnetic resonance imaging in classification of congenital muscular dystrophies with brain abnormalities. Ann Neurol 42: 50-59.

van Reeuwijk J, Janssen M, van den Elzen C, Beltran-Valero de Bernabé D, Sabatelli P, Merlini L, Boon M, Scheffer H, Brockington M, Muntoni F, et al. 2005. POMT2 mutations cause $\alpha$-dystroglycan hypoglycosylation and Walker-Warburg syndrome. J Med Genet 42: 907-912.

van Reeuwijk J, Maugenre S, van den Elzen C, Verrips A, Bertini E, Muntoni F, Merlini L, Scheffer H, Brunner HG, Guicheney P, et al. 2006. The expanding phenotype of POMT1 mutations: From Walker-Warburg syndrome to congenital muscular dystrophy, microcephaly, and mental retardation. Hum Mutat 27: 453-459.

van Reeuwijk J, Grewal PK, Salih MA, Beltrán-Valero de Bernabé D, McLaughlan JM, Michielse CB, Herrmann R, Hewitt JE, Steinbrecher A, Seidahmed $\mathrm{MZ}$, et al. 2007. Intragenic deletion in the large gene causes Walker-Warburg Syndrome. Hum Genet 121: $685-690$. 
van Reeuwijk J, Olderode-Berends MJ, Van den Elzen C, Brouwer OF, Roscioli T, van Pampus MG, Scheffer H, Brunner HG, van Bokhoven H, Hol FA, et al. 2010. A homozygous FKRP start codon mutation is associated with Walker-Warburg syndrome, the severe end of the clinical spectrum. Clin Genet 78: 275-281.

van Straaten HL, van Tintelen JP, Trijbels JM, van den Heuvel LP, Troost D, Rozemuller JM, Duran M, de Vries LS, Schuelke M, Barth PG. 2005. Neonatal lactic acidosis, complex I/IV deficiency, and fetal cerebral disruption. Neuropediatrics 36: 193-199.

Vigliano P, Dassi P, Blasi CD, Mora M, Jarre L. 2009. LAMA2 stop-codon mutation: Merosin-deficient congenital muscular dystrophy with occipital polymicrogyria, epilepsy and psychomotor regression. Eur J Paediatr Neurol 13: $72-76$.
Wieck G, Leventer RJ, Squier WM, Jansen A, Andermann E, Dubeau F, Ramazzotti A, Guerrini R, Dobyns WB. 2005. Periventricular nodular heterotopia with overlying polymicrogyria. Brain 128: 2811-2821.

Wirrell EC, Wong-Kisiel LCL, Mandrekar J, Nickels KC. 2013. What predicts enduring intractability in children who appear medically intractable in the first 2 years after diagnosis? Epilepsia 54: 1056-1064.

Zhang J, Neal J, Lian G, Hu J, Lu J, Sheen V. 2013. Filamin A regulates neuronal migration through brefeldin A-inhibited guanine exchange factor 2-dependent Arf1 activation. J Neurosci 33: 15735-15746.

Zoncu R, Efeyan A, Sabatini DM. 2011. mTOR: From growth signal integration to cancer, diabetes and ageing. Nat Rev Mol Cell Biol 12: 21-35. 


\title{
$\&_{\mathrm{CSH}}^{\infty} \&$ Cold Spring Harbor

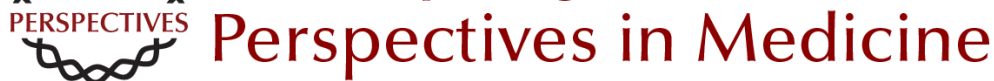

\section{Malformations of Cortical Development and Epilepsy}

\author{
A. James Barkovich, William B. Dobyns and Renzo Guerrini
}

Cold Spring Harb Perspect Med 2015; doi: 10.1101/cshperspect.a022392

Subject Collection Epilepsy: The Biology of a Spectrum Disorder

The Epilepsy Spectrum: Targeting Future Research Challenges

Gregory L. Holmes and Jeffrey L. Noebels

Role of Sodium Channels in Epilepsy

David I. Kaplan, Lori L. Isom and Steven Petrou

\section{Mechanisms of Action of Antiseizure Drugs and the Ketogenic Diet Michael A. Rogawski, Wolfgang Löscher and Jong M. Rho}

Epilepsy and Autism

Ashura W. Buckley and Gregory L. Holmes

Immunity and Inflammation in Epilepsy Annamaria Vezzani, Bethan Lang and Eleonora Aronica

Hyperpolarization-Activated Cyclic Nucleotide-Gated (HCN) Channels in Epilepsy Gary P. Brennan, Tallie Z. Baram and Nicholas P. Poolos

The Role of Calcium Channels in Epilepsy Sanjeev Rajakulendran and Michael G. Hanna Interneuron Transplantation as a Treatment for Epilepsy

Robert F. Hunt and Scott C. Baraban
Common Mechanisms Underlying

Epileptogenesis and the Comorbidities of

Epilepsy

Andrey Mazarati and Raman Sankar

The Diathesis-Epilepsy Model: How Past Events Impact the Development of Epilepsy and Comorbidities Christophe Bernard

Potassium Channels in Epilepsy Rüdiger Köhling and Jakob Wolfart

\section{GABAergic Synchronization in Epilepsy} Roustem Khazipov

\section{Status Epilepticus}

Syndi Seinfeld, Howard P. Goodkin and Shlomo Shinnar

Neonatal and Infantile Epilepsy: Acquired and Genetic Models Aristea S. Galanopoulou and Solomon L. Moshé

Epigenetics and Epilepsy David C. Henshall and Katja Kobow

Microcircuits in Epilepsy: Heterogeneity and Hub Cells in Network Synchronization Anh Bui, Hannah K. Kim, Mattia Maroso, et al.

For additional articles in this collection, see http://perspectivesinmedicine.cshlp.org/cgi/collection/ 